\title{
Highly time-resolved urban aerosol characteristics during springtime in Yangtze River Delta, China: insights from soot particle aerosol mass spectrometry
}

\author{
Junfeng Wang ${ }^{1,2}$, Xinlei Ge ${ }^{1}$, Yanfang Chen ${ }^{1}$, Yafei Shen ${ }^{1}$, Qi Zhang ${ }^{3,1}$, Yele Sun ${ }^{4}$, Jianzhong Xu ${ }^{5}$, Shun Ge ${ }^{6}$, \\ Huan Yu ${ }^{1}$, and Mindong Chen ${ }^{1}$ \\ ${ }^{1}$ Jiangsu Key Laboratory of Atmospheric Environment Monitoring and Pollution Control (AEMPC), Collaborative Innovation \\ Center of Atmospheric Environment and Equipment Technology (CIC-AEET), School of Environmental Science and \\ Engineering, Nanjing University of Information Science \& Technology, Nanjing 210044, China \\ ${ }^{2}$ Yangzhou Environmental Monitoring Center, Yangzhou 225007, China \\ ${ }^{3}$ Department of Environmental Toxicology, University of California at Davis, Davis, California 95616, USA \\ ${ }^{4}$ State Key Laboratory of Atmospheric Boundary Layer Physics and Atmospheric Chemistry, Institute of Atmospheric \\ Physics, Chinese Academy of Sciences, Beijing 100029, China \\ ${ }^{5}$ State Key Laboratory of Cryospheric Sciences, Cold and Arid Regions Environmental and Engineering Research Institute, \\ Chinese Academy of Sciences, Lanzhou 730000, China \\ ${ }^{6}$ Nanjing Tianbo Environmental Technology Co., Ltd, Nanjing 210047, China
}

Correspondence to: Xinlei Ge (caxinra@163.com) and Mindong Chen (chenmdnuist@163.com)

Received: 15 March 2016 - Published in Atmos. Chem. Phys. Discuss.: 21 March 2016

Revised: 27 June 2016 - Accepted: 30 June 2016 - Published: 25 July 2016

\begin{abstract}
In this work, the Aerodyne soot particle - aerosol mass spectrometer (SP-AMS) was deployed for the first time during the spring of 2015 in urban Nanjing, a megacity in the Yangtze River Delta (YRD) of China, for online characterization of the submicron aerosols $\left(\mathrm{PM}_{1}\right)$. The SP-AMS enables real-time and fast quantification of refractory black carbon $(r \mathrm{BC})$ simultaneously with other non-refractory species (ammonium, sulfate, nitrate, chloride, and organics). The average $\mathrm{PM}_{1}$ concentration was found to be $28.2 \mu \mathrm{g} \mathrm{m}^{-3}$, with organics $(45 \%)$ as the most abundant component, following by sulfate $(19.3 \%)$, nitrate $(13.6 \%)$, ammonium $(11.1 \%)$, $r \mathrm{BC}(9.7 \%)$, and chloride $(1.3 \%)$. These $\mathrm{PM}_{1}$ species together can reconstruct $\sim 44 \%$ of the light extinction during this campaign based on the IMPROVE method. Chemically resolved mass-based size distributions revealed that small particles especially ultrafine ones $(<100 \mathrm{~nm}$ vacuum aerodynamic diameter) were dominated by organics and $r \mathrm{BC}$, while large particles had significant contributions from secondary inorganic species. Source apportionment of organic aerosols (OA) yielded four OA subcomponents, including hydrocarbon-like OA (HOA), cooking-related OA
\end{abstract}

(COA), semi-volatile oxygenated OA (SV-OOA), and lowvolatility oxygenated OA (LV-OOA). Overall, secondary organic aerosol (SOA, equal to the sum of SV-OOA and LVOOA) dominated the total OA mass $(55.5 \%)$, but primary organic aerosol (POA, equal to the sum of HOA and COA) can outweigh SOA in the early morning and evening due to enhanced human activities. High OA concentrations were often associated with high mass fractions of POA and $r \mathrm{BC}$, indicating the important role of anthropogenic emissions during heavy pollution events. The diurnal cycles of nitrate, chloride, and SV-OOA both showed good anti-correlations with air temperatures, suggesting their variations were likely driven by thermodynamic equilibria and gas-to-particle partitioning. On the other hand, in contrast to other species, sulfate, and LV-OOA concentrations increased in the afternoon, and showed no positive correlations with relative humidity $(\mathrm{RH})$, likely indicating the contribution from photochemical oxidation is dominant over that of aqueous-phase processing for their formations. The bivariate polar plots show that the SV-OOA was formed locally, and the variations of hydrogento-carbon $(\mathrm{H} / \mathrm{C})$ and oxygen-to-carbon $(\mathrm{O} / \mathrm{C})$ ratios in the 
Van Krevelen space further suggests an evolution pathway of SV-OOA to LV-OOA. Our findings regarding springtime aerosol chemistry in Nanjing may have important implications for the air quality remediation in the densely populated regions.

\section{Introduction}

In recent years, high concentrations of fine particulate matter $\left(\mathrm{PM}_{2.5}\right)$ have been frequently observed (Hu et al., 2015), in accompanying with the visibility impairment and occurrence of haze events across large parts of China. $\mathrm{PM}_{2.5}$ also affects human health (e.g., Pope and Dockery, 2006; Cao et al., 2012), regional and global climate directly by absorbing and scattering solar radiation or indirectly by acting as cloud condensation nuclei and ice nuclei (e.g., Ghan and Schwartz, 2007; Pöschl, 2005), and the earth's ecosystem (Carslaw et al., 2010). These effects are predominantly dependent upon the physical and chemical characteristics of fine particles, such as mass concentration, chemical composition, size distribution, and hygroscopicity, all of which are influenced by the emission sources and transformation and evolution processes in the atmosphere.

The Yangtze River Delta (YRD) region is one of the most populated and economically developed areas in China, but it is also faced with severe air pollution lately. Nanjing, as one of the major megacities in this region, has a daily $\mathrm{PM}_{2.5}$ mass concentration varying between $33-234 \mu \mathrm{g} \mathrm{m}^{-3}$ during November 2011-August 2012, with an mean value of $106 \mu \mathrm{g} \mathrm{m}^{-3}$, which is 4.2 times the WHO air quality standard of $25 \mu \mathrm{g} \mathrm{m}^{-3}$ (Shen et al., 2014). $\mathrm{PM}_{2.5}$ pollution is significantly elevated during hazy days, for example, a daily average of $282 \mu \mathrm{g} \mathrm{m}^{-3}$ was observed for a heavily polluted day (Fu et al., 2008). A number of studies regarding aerosol chemistry in Nanjing have been conducted, and identified various inorganic components (sulfate, nitrate, ammonium, and heavy metals, etc.) (e.g., Wang et al., 2003; Hu et al., 2012; Qi et al., 2016) and hundreds of organic species (carboxylic/dicarboxylic acids, amines and amino acids, polycyclic aromatic hydrocarbons, etc.) (Wang et al., 2011, 2002; Yang et al., 2005; Wang et al., 2009) that contribute to the aerosol mass. However, past studies mostly employed filterbased sampling technique, which, due to low time resolution (a few hours to days), is often incapable of capturing details of the atmospheric evolution processes during the typical lifecycle of aerosols (Wexler and Johnston, 2008). Subsequent offline analyses may also introduce artifacts as some semi-volatile species can evaporate during sampling and storage (Dong et al., 2012).

On the other hand, in the past 15 years, the Aerodyne aerosol mass spectrometer (AMS) (Canagaratna et al., 2007) has been widely used, and was proven to be powerful for realtime online measurements of size-resolved chemical compo- sitions of submicron aerosols $\left(\mathrm{PM}_{1}\right)$ with very fine time resolution (seconds to minutes) (Zhang et al., 2007a; Jimenez et al., 2009). The development of Aerodyne AMS began with the invention of quadruple AMS (Q-AMS) (Jayne et al., 2000), following by the compact time-of-flight AMS (CToF-AMS) (Drewnick et al., 2005), high-resolution time-offlight AMS (HR-ToF-AMS) (DeCarlo et al., 2006) and the soot particle AMS (SP-AMS) (Onasch et al., 2012). There is also an aerosol chemical speciation monitor (ACSM) $(\mathrm{Ng}$ et al., 2011) and its updated version of ToF-ACSM (Fröhlich et al., 2013), which are in particular designed for longterm unattended aerosol measurements. SP-AMS is the most advanced version, which in principle incorporates the single particle soot photometer (SP2) into the HR-ToF-AMS, and upgraded with a laser vaporizer for detecting refractory black carbon $(r \mathrm{BC})$ and associated/coated species that cannot be measured by other types of AMS.

Recently, the Aerodyne AMS has been deployed widely in China (particularly Beijing) (e.g., Xu et al., 2014 and references therein; Sun et al., 2014; Yeung et al., 2014; Zhang et al., 2014; Li et al., 2015; Shen et al., 2015; Sun et al., 2015a, b; Yan et al., 2015; Zhang et al., 2015; Tang et al., 2016; J. K. Zhang et al., 2016; Jiang et al., 2015; Chen et al., 2015; Xu et al., 2015; Du et al., 2015; Sun et al., 2016; Wang et al., 2015; Han et al., 2015; Q. Wang et al., 2016). However, only a few field campaigns were conducted in the YRD region. Huang et al. (2012) deployed an HR-ToF-AMS together with an SP2 in Shanghai during the 2010 Shanghai World Expo, and in Jiaxing during summer and winter of 2010 (Huang et al., 2013). In urban Nanjing, an ACSM was applied for characterizing $\mathrm{PM}_{1}$ during summer and autumn harvest seasons (Zhang et al., 2015), and during December 2013 to investigate a few heavy haze events (Y. J. Zhang et al., 2016). In addition, a Q-AMS was deployed in Nanjing to investigate the effects of $\mathrm{PM}_{1}$ on visibility during January 2013 (Shen et al., 2015). Furthermore, a recent study by J. Wang et al. (2016) reported the observation of fullerene soot in suburban Nanjing using an SP-AMS. Nevertheless, many questions remain with regard to aerosol chemistry, sources, and processes in this region. Moreover, none of the previous AMS measurements studied the aerosol characteristics during springtime in Nanjing, yet the springtime aerosols may have different behaviors than those in other seasons, when aerosols are likely influenced significantly by emissions from biomass burning, coal burning etc. For these reasons, we report in this work the real-time measurement results on urban fine aerosols in Nanjing using the SP-AMS during spring in 2015. The rich highly time-resolved, highly chemical-resolved mass spectral data, as well as chemically resolved size distributions of different aerosol species obtained for the first time in Nanjing during this study, can allow us to conduct in-depth analyses, and better understand the characteristics, sources and relevant transformation processes of ambient aerosols. The findings for such a megacity are also valuable to the PanEurasian Experiment (PEEX) infrastructure which aims to 
resolve the major uncertainties in Earth system science and global sustainability issues (Kulmala et al., 2015).

\section{Experiments}

\subsection{Sampling site and instrumentation}

The field campaign was conducted in the environment monitoring station of Nanjing Olympic center $\left(32^{\circ} 0^{\prime} 33.00^{\prime \prime} \mathrm{N}\right.$, $118^{\circ} 44^{\prime} 9.53^{\prime \prime}$ E) from 13 to 29 April 2015. Details of the sampling site are shown in Fig. S1 in the Supplement. The site was surrounded by residential buildings, close to a few urban arterial roads $(\sim 85 \mathrm{~m}$ northwest of Huangshan Road, $\sim 200 \mathrm{~m}$ northeast to Mengdu Street and $\sim 425 \mathrm{~m}$ southwest of Xinglong Street). There are also a restaurant $(\sim 50 \mathrm{~m})$, a student cafeteria $(\sim 300 \mathrm{~m})$, and the Nanjing Cigarette Factory ( $\sim 480 \mathrm{~m}$ southeast) around the site.

The sampling inlet was installed outside the fifth floor of the building ( $\sim 12 \mathrm{~m}$ above the ground), with a $\mathrm{PM}_{2.5} \mathrm{cy}-$ clone (URG Corp., Chapel Hill, NC, USA) to remove coarse particles. Ambient particles were dried $(\mathrm{RH}<10 \%)$ via a diffusion dryer filled with silica gel before entering into the SPAMS. The sampling line $(\sim 2 \mathrm{~m}$ long $)$ was assembled using stainless steel tubing and proper fittings. Air flow was controlled at around $\sim 5 \mathrm{~L} \mathrm{~min}^{-1}$, with a flow rate into the SPAMS at $\sim 80 \mathrm{~cm}^{3} \mathrm{~min}^{-1}$.

The SP-AMS can measure non-refractory (NR) $\mathrm{PM}_{1}$ components including ammonium, nitrate, sulfate, chloride, and organics similar to other types of AMS via a thermal Tungsten heater. Moreover, it can also measure $r \mathrm{BC}$ and inorganic/organic species that coated on the $r \mathrm{BC}$ cores, as it is equipped with an intracavity $\mathrm{Nd}$ :YAG laser vaporizer (1064 nm) (Onasch et al., 2012). During this campaign, the instrument was switched between "laser on" and "laser off" settings, and between V-mode (better for mass quantification) and W-mode (better chemical resolution, $\sim 5000$ in this study), with one cycle including six menu settings (M1: laser on V-mode; M2: laser off V-mode; M3: laser on W-mode; M4: laser off W-mode; M7: laser on PToF-mode; M8: laser off PToF-mode). Each menu was set to $2.5 \mathrm{~min}$, thus a full running cycle lasted for $15 \mathrm{~min}$. The PToF-mode was under $\mathrm{V}$-mode, but was tuned in particular for measuring particle sizes. The Tungsten heater was always turned on and kept at $\sim 600^{\circ} \mathrm{C}$.

The SP-AMS, in conjunction with a scanning mobility particle sizer (SMPS) (TSI inc., Shoreview, MN, USA) was calibrated for mass quantification (e.g., ionization efficiency) using size-selected (250 and $300 \mathrm{~nm}$ ) monodisperse ammonium nitrate particles following the procedures detailed in Jimenez et al. (2003). Pure ammonium sulfate was used to determine the relative ionization efficiency (RIE) of sulfate to nitrate (Setyan et al., 2012). Quantification of $r$ BC was calibrated using Regal Black (REGAL 400R pigment black, Cabot Corp.) particles according to the procedures reported in Onasch et al. (2012). Note that the aqueous solution of Regal Black was sonicated during calibration to maintain a relative stable aerosol flow. RIEs of ammonium, nitrate, sulfate, chloride, organics and $r \mathrm{BC}$ were determined to be $3.15,1.05$, $1.20,1.3,1.4$, and 0.33 , respectively. On the other hand, particle sizing was calibrated using standard polystyrene latex (PSL) spheres (Duke Scientific Corp., Palo Alto, CA, USA) across $100-700 \mathrm{~nm}$ range. Flow rate was also calibrated prior to the measurement.

Concentrations of gaseous species, e.g., carbon monoxide (CO) (Model T300, Teledyne API, USA), ozone $\left(\mathrm{O}_{3}\right)$ (Model EC9810, Ecotech Pty Ltd, Australia), nitrogen dioxide $\left(\mathrm{NO}_{2}\right)$ and sulfur dioxide $\left(\mathrm{SO}_{2}\right)$ (Model LGH-01, Anhui Landun, China), and meteorological data including air temperature $(T)$, relative humidity $(\mathrm{RH})$, visibility $(\mathrm{km})$, wind speed (WS) and wind direction (WD) were acquired at the same site. $\mathrm{PM}_{2.5}$ and $\mathrm{PM}_{10}$ mass concentrations were also recorded (BAM-1020, Met One Instruments, Inc., USA), in parallel with the SP-AMS measurement.

\subsection{Data treatment and source analyses}

The SP-AMS data were post-processed by using the Igor-based standard ToF-AMS Analysis Toolkit SQUIRREL v1.56D and PIKA v1.15D, available at http://cires1.colorado.edu/jimenez-group/ ToFAMSResources/ToFSoftware/index.html. Note all mass concentrations reported here were calculated from the HR fitted results on V-mode data. A collection efficiency is typically used to account for the particles that are not collected and measured by the instrument; this is due to the particles lost during passage through inlet, time-of-flight chamber and bouncing from the vaporizer. For the SP-AMS, the $\mathrm{CE}$ of the laser vaporizer is mainly governed by particle divergence, while for the Tungsten vaporizer, the $\mathrm{CE}$ is governed mainly by the bouncing effects (Matthew et al., 2008). A CE value of 0.5 is valid and used commonly for the AMS measurements for most environments (Canagaratna et al., 2007). Nevertheless, Middlebrook et al. (2012) further investigated this issue, and found that high aerosol acidity, high mass fractions of ammonium nitrate, and high sampling line RH can increase the $\mathrm{CE}$, and composition-dependent $\mathrm{CE}$ parameterization. For our data set, we found that the composition-dependent $\mathrm{CE}$ rather than a constant $\mathrm{CE}=0.5$ has negligible effects on the quantification of aerosol species, as the particles were neutralized (Fig. 3a), the mass fraction of ammonium nitrate were $<40 \%$ in almost all cases, and also the sampling line RH was below $10 \%$. And in fact, the $\mathrm{PM}_{1}$ mass concentrations quantified by using the composition-dependent $\mathrm{CE}$ correlate a bit worse with the $\mathrm{PM}_{2.5}$ concentrations than ones using $\mathrm{CE}=0.5$. Thus, a constant $\mathrm{CE}$ of 0.5 , in keeping with many other AMS studies, was employed for this data set. 
Unless specified, the concentrations of ammonium, sulfate, nitrate, chloride, and organics are from M2 setting (Tungsten vaporizer only), while the $r \mathrm{BC}$ data is from M1 setting (dual vaporizers: Tungsten + laser) in this paper. The meteorological data (RH, $T$, WS, WD, and visibility), concentrations of gas-phase species $\left(\mathrm{CO}, \mathrm{NO}_{2}, \mathrm{SO}_{2}\right.$, and $\left.\mathrm{O}_{3}\right)$ and $\mathrm{PM}_{2.5}$ were averaged into hourly data for comparisons with the SP-AMS data. The data reported are at local time, e.g., Beijing (BJ) Time.

Positive matrix factorization (PMF) (Paatero and Tapper, 1994) was applied on the high-resolution mass spectra (HRMS) of organic aerosol (OA) obtained under laser off W-mode (M4 setting) to elucidate the OA sources/processes. We used the PMF evaluation tool version 2.08A (downloaded from: http://cires1.colorado.edu/jimenez-group/wiki/index. php/PMF-AMS_Analysis_Guide) (Ulbrich et al., 2009) to investigate the PMF results by varying the number of factors (from 2 to 8 factors) and rotations (" $f_{\text {peak }}$ ", from -1 to 1 with an increment of 0.1 ). Only ions with $m / z$ less than or equal to 180 were included in the analyses. Following the instruction detailed by Zhang et al. (2011), the 4-factor solution (at $f_{\text {peak }}=-0.1$ ) was chosen as the optimal solution, as the 3 -factor solution cannot separate the hydrocarbon-like OA (HOA) and cooking OA (COA) (Fig. S2). For the 5-factor solution (Fig. S3), Factor 2 and Factor 4 are clearly a split of the SVOOA from the 4-factor solution $\left(r^{2}=0.89\right.$ and slope of 1.05, Fig. S3c); Factor 2 of 5-factor solution also shows much weaker correlations with nitrate than SVOOA of 4factor solution does ( $r=0.07$ vs. 0.49$)$. A summary of the key diagnostic plots are provided in Fig. S4. Detailed discussion of the PMF results is presented in Sect. 3.5. Note we found no significant differences between the PMF source apportionment results from the HRMS of OA (without $r \mathrm{BC}$ ) obtained with dual-vaporizers setting (M3 setting) and current results (M4 setting, Tungsten vaporizer only), as the OA HRMS acquired under these two circumstances were very similar (details in Sect. 3.4).

Note that the elemental ratios shown throughout the paper were all calculated based on the method proposed by Aiken et al. (2008) (referred to as A-A method). Recently, Canagaratna et al. (2015) improved this methodology by using specific ion fragments as markers to calculate the $\mathrm{O} / \mathrm{C}$ and $\mathrm{H} / \mathrm{C}$ ratios (referred to as I-A method). The I-A method increased the $\mathrm{O} / \mathrm{C}$ ratio, $\mathrm{H} / \mathrm{C}$ ratio, and the $\mathrm{OM} / \mathrm{OC}$ ratio from the values calculated from the A-A method, on average, by 28,10 , and $8 \%$, respectively (Fig. S5). In this work, we used the results from the A-A method for consistency and comparisons with previous AMS measurements.

\section{Results and discussion}

\subsection{Mass concentrations, chemical compositions, and diurnal changes}

The temporal variations of meteorological parameters, concentrations of the gas pollutants, concentrations, and mass fractions of different $\mathrm{PM}_{1}$ components, and the $\mathrm{PM}_{2.5}$ mass loadings (from Met one BAM-1020) over the sampling period are illustrated in Fig. 1. During this study, the mean temperature was $18.5^{\circ} \mathrm{C}, \mathrm{RH}$ on average was $64 \%$, and wind predominantly blew from the southeast and southwest (Fig. S6). The SP-AMS $\mathrm{PM}_{1}$ concentrations ranged from 5.1 to $97.9 \mu \mathrm{g} \mathrm{m}^{-3}$, with an average of $28.2 \mu \mathrm{g} \mathrm{m}^{-3}$. Note this average $\mathrm{PM}_{1}$ concentration is significantly lower than those observed during summer $\left(38.5 \mathrm{\mu g} \mathrm{m}^{-3}\right)$, autumn $\left(46.4 \mu \mathrm{g} \mathrm{m}^{-3}\right)$ and winter $\left(89.3 \mu \mathrm{g} \mathrm{m}^{-3}\right.$ ) (Y. J. Zhang et al., 2015, 2016), showing that the air during springtime in Nanjing is cleaner than in other seasons. The variations of $\mathrm{PM}_{1}$ concentrations also match very well with $\mathrm{PM}_{2.5}$ concentrations (Pearson's $r^{2}=0.72$ ), and on average $\mathrm{PM}_{1}$ accounts for $\sim 54 \%$ of the $\mathrm{PM}_{2.5}$ mass. This ratio appears to be a bit low, likely due to the uncertainty of CE of the SP-AMS.

The average $\mathrm{PM}_{1}$ composition is shown in Fig. 2a. The most abundant component is found to be organics $(45.0 \%)$, following by sulfate $(19.3 \%)$, nitrate (13.6\%), ammonium $(11.1 \%), r \mathrm{BC}(9.7 \%)$ and chloride $(1.3 \%)$. Figure $2 \mathrm{~b}$ further shows changes of the $\mathrm{PM}_{1}$ chemical compositions in different concentration bins. It can be seen that although most $\mathrm{PM}_{1}$ mass loadings are within $10-40 \mu \mathrm{g} \mathrm{m}^{-3}$, high loading periods tend to have higher mass contributions from organics and $r \mathrm{BC}$, and less contributions from secondary inorganic species, indicating that high PM events were influenced significantly by local fresh emissions.

The molar ratio of inorganic anions (sulfate, nitrate, and chloride) to cations (ammonium) is 1.05 (Fig. 3a) (Zhang et al., 2007b). Considering that a small fraction of sulfate, nitrate, and chloride are possibly associated with metal cations, such as $\mathrm{Na}^{+}, \mathrm{K}^{+}$, and $\mathrm{Ca}^{2+}$, etc. it can be concluded that the NR-PM ${ }_{1}$ was neutral throughout the study. On the other hand, the molar ratio of inorganic anions to ammonium is on average 1.17 (Fig. 3b) when dual vaporizers are on. This may be partially due to variations of ionization/collection efficiencies of the measured species as the addition of a laser beam may change the distribution of vaporized species inside the ion chamber, and also because of the detection of sulfate, nitrate, and chloride bonded with metal cations under the dual vaporizers. These species do not evaporate on the Tungsten vaporizer under the laser-off mode. Indeed, more metal signals were observed with the dual vaporizers, as shown in Fig. S7.

Figure 2c shows the average diurnal changes of organics, sulfate, nitrate, chloride, and $r \mathrm{BC}$. Sulfate concentrations are slightly higher during daytime than during nighttime, indicating a significant contribution from photochemi- 


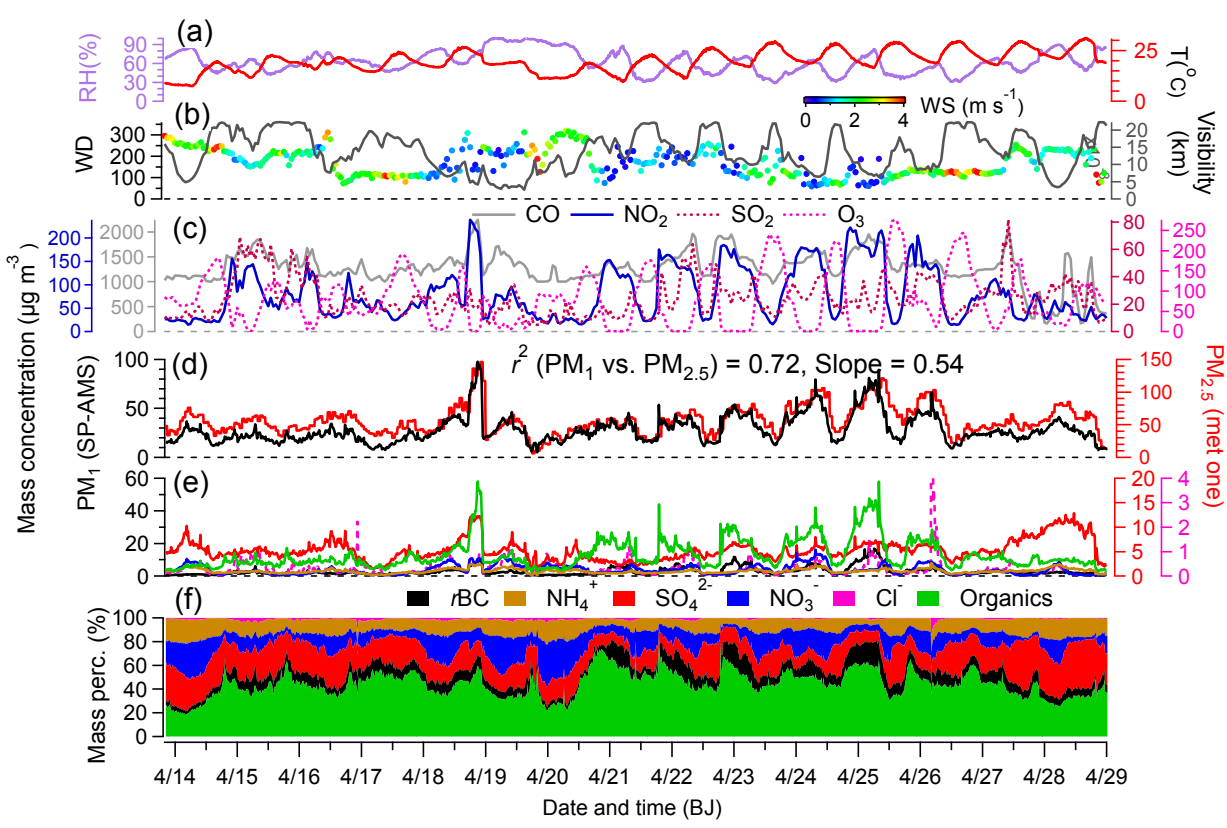

Figure 1. Time series of (a) relative humidity (RH) and temperature ( $T$ ); (b) wind direction (WD) colored by wind speed (WS, $\mathrm{m} \mathrm{s}^{-1}$ ) and visibility (km); (c) mass concentrations of $\mathrm{CO}, \mathrm{NO}_{2}, \mathrm{SO}_{2}$ and $\mathrm{O}_{3}$ (hourly data); (d) mass concentrations of PM $\mathrm{PM}_{1}$ measured by the SP-AMS, and $\mathrm{PM}_{2.5}$ measured by the co-located Met One $\mathrm{PM}_{2.5}$ analyzer; (e) mass concentrations of $r \mathrm{BC}$, ammonium, sulfate, nitrate, chloride, and organics; and (f) mass contributions $(\%)$ of the six $\mathrm{PM}_{1}$ components (BJ, Beijing).

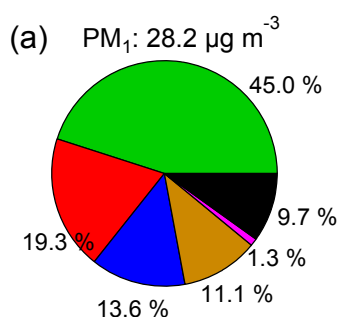

(b)

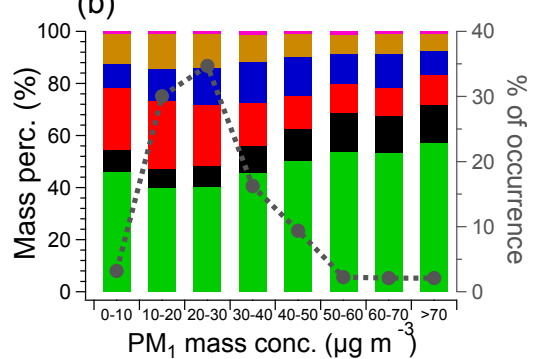

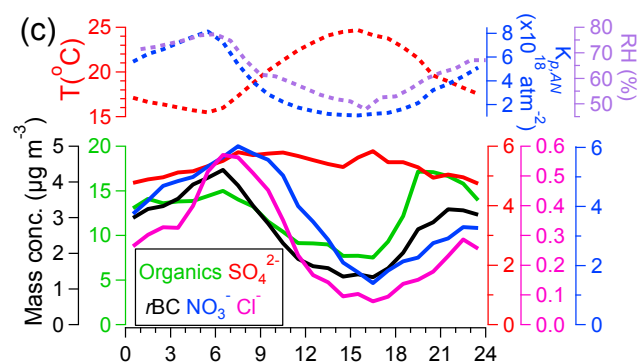

(d)

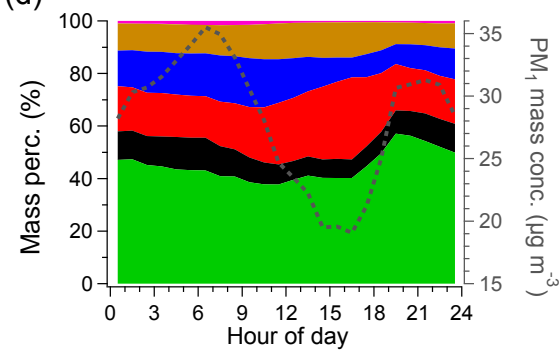

Figure 2. (a) Campaign-averaged mass contributions of organics, sulfate, nitrate, ammonium, chloride, and $r \mathrm{BC}$ to the total $\mathrm{PM}$; (b) mass percentages of the six $\mathrm{PM}_{1}$ species (left $y$ axis) and fractions of the number of data points to the total number of data points for PM 1 at different concentration bins (right $y$ axis); (c) diurnal patterns of mass concentrations of the major $\mathrm{PM}_{1}$ species (bottom panel), temperature

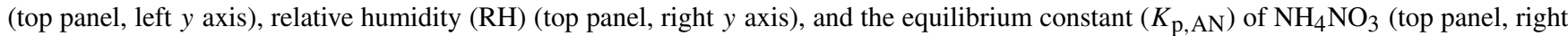
$y$ axis) $\left(K_{\mathrm{p}, \mathrm{AN}}=K_{\mathrm{p}, \mathrm{AN}}(298) \exp \left\{a\left(\frac{298}{T}-1\right)+b\left[1+\ln \left(\frac{298}{T}\right)-\frac{298}{T}\right]\right\}\right.$; for reaction $\mathrm{NH}_{4} \mathrm{NO}_{3}(\mathrm{p}) \leftrightarrow \mathrm{NH}_{3}(\mathrm{~g})+\mathrm{HNO}_{3}(\mathrm{~g}) . K_{\mathrm{p}, \mathrm{AN}}(298)$ is the equilibrium constant at $298 \mathrm{~K}\left(3.36 \times 10^{16} \mathrm{~atm}^{-2}\right), a=75.11$, and $b=-13.5$; Seinfeld and Pandis, 2006); (d) diurnal variations of mass fractional contributions of the six $\mathrm{PM}_{1}$ species (left $y$ axis), and the $\mathrm{PM}_{1}$ mass concentrations (right $y$ axis). 

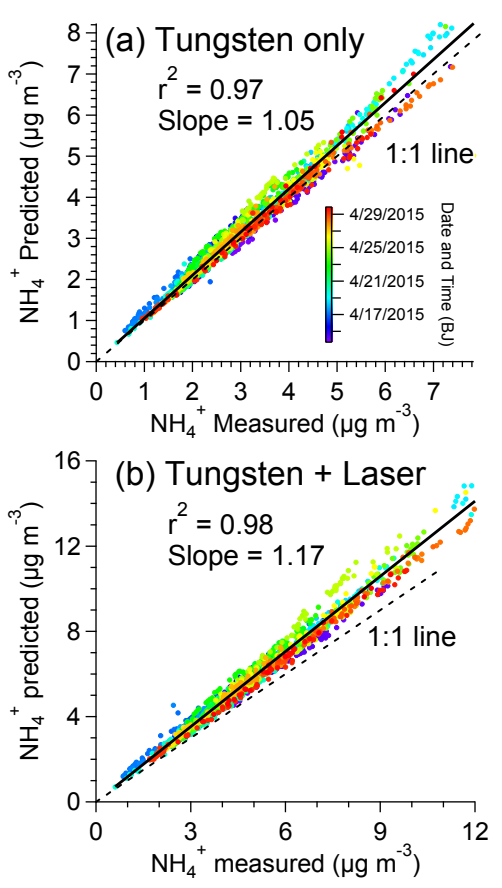

Figure 3. Scatter plots of the predicted $\mathrm{NH}_{4}^{+}$vs. measured $\mathrm{NH}_{4}^{+}$ concentrations (colored by time), in the case of (a) Tungsten vaporizer only, and (b) dual vaporizers (Tungsten + laser). The predicted values were calculated according to the formula: $\mathrm{NH}_{4}^{+}$predicted $=18 \times\left(2 \times \mathrm{SO}_{4}^{2-} / 96+\mathrm{NO}_{3}^{-} / 62+\mathrm{Cl}^{-} / 35.5\right)($ Zhang et al., 2007b).

cal reactions. Sulfate also shows the least variations among all species, reflecting its regional behavior. Except for sulfate, all other species present a dual-peak pattern, with one peak in the early morning and another one in the early evening. The peaks of $r \mathrm{BC}$ and organics are likely due to local traffic/cooking activities (see details in Sect. 3.5), while the behavior of nitrate is likely driven by the thermodynamic gasparticle partitioning: $\mathrm{NH}_{3}(\mathrm{~g})+\mathrm{HNO}_{3}(\mathrm{~g}) \leftrightarrow \mathrm{NH}_{4} \mathrm{NO}_{3}(\mathrm{p})$ as it shows good anti-correlations with the diurnal changes of temperatures $(r=-0.72$ for nitrate vs. $T)$. The good correlations between the diurnal cycles of nitrate and $\mathrm{RH}$, in particular during nighttime, suggest a nighttime formation pathway of nitrate, e.g., $\mathrm{N}_{2} \mathrm{O}_{5}+\mathrm{H}_{2} \mathrm{O}=2 \mathrm{HNO}_{3}$ and $\mathrm{HNO}_{3}+\mathrm{NH}_{3}=\mathrm{NH}_{4} \mathrm{NO}_{3}$. Furthermore, we calculated the diurnal variations of the equilibrium constant of $\mathrm{NH}_{4} \mathrm{NO}_{3}$ $\left(K_{\mathrm{p}, \mathrm{AN}}\right)$ (Seinfeld and Pandis, 2006; Young et al., 2016) in Fig. 2c. The $K_{\mathrm{p}, \mathrm{AN}}$ displays a similar trend as nitrate $(r=0.68)$, providing strong evidence that nitrate variations were governed mainly by the thermodynamic equilibrium. Chloride shows similar behavior as nitrate, indicating it is driven by the equilibrium $\mathrm{NH}_{3}(\mathrm{~g})+\mathrm{HCl}(\mathrm{g}) \leftrightarrow \mathrm{NH}_{4} \mathrm{Cl}(\mathrm{p})$ as well $(r=-0.76$ for chloride vs. $T$ ). Therefore, when temperature rises, more $\mathrm{NH}_{4} \mathrm{NO}_{3}$ and $\mathrm{NH}_{4} \mathrm{Cl}$ can dissociate into gaseous $\mathrm{NH}_{3}, \mathrm{HNO}_{3}$ and $\mathrm{HCl}$, mass loadings of particle- phase nitrate and chloride decrease correspondingly, and vice versa.

In order to further elucidate the formation processes of sulfate, we calculated the oxidation ratios of sulfur $\left(f_{\mathrm{S}}\right)$ (Fig. 4a), defined as $f_{\mathrm{S}}=n \mathrm{SO}_{4}^{2-} /\left(n \mathrm{SO}_{4}^{2-}+n \mathrm{SO}_{2}\right)$ (Xu et al., 2014), indicating the conversion of $\mathrm{SO}_{2}$. Here $n \mathrm{SO}_{4}^{2-}$ and $n \mathrm{SO}_{2}$ are the molar quantities of particle-phase sulfate, and gas-phase $\mathrm{SO}_{2}$, respectively. Diurnal variations of $f_{\mathrm{S}}$ and $\mathrm{RH}$ are presented in Fig. $4 \mathrm{~b}$, and Fig. $4 \mathrm{c}$ shows variations of sulfate and nitrate concentrations with RH. The diurnal profile of $f_{\mathrm{S}}$ shows a negative correlation with that of RH $(r=-0.52)$, and mass concentrations of sulfate even drop under high RH conditions, indicating an insignificant role of aqueous-phase processing for sulfate formation during this campaign. On the other hand, the $f_{\mathrm{S}}$ reaches a maximum around $3 \mathrm{pm}$. Note the afternoon rise of $f_{\mathrm{S}}$ and sulfate may be affected by the down mixing of sulfate formed earlier, however, since concentrations of all other aerosol species that mix with sulfate decrease significantly, we postulate that the increase of $f_{\mathrm{S}}$ likely suggest the photochemical production of sulfate in the afternoon.

\subsection{Chemically resolved size distributions}

The campaign-averaged mass-based size distributions, fractional contributions, and diurnal size distributions (image plots) of the major $\mathrm{PM}_{1}$ species are depicted in Fig. 5 (temporal variations of the mass-based size distributions of these $\mathrm{PM}_{1}$ species over the whole measurement period are provided in Fig. S8). Note the size distribution of $r \mathrm{BC}$ in these plots were scaled from the size distribution of $m / z 24\left(\mathrm{C}_{2}^{+}\right)$, as other major $r \mathrm{BC}$ ion clusters may be heavily influenced by other ions, such as $\mathrm{C}^{+}$signal but from organics at $m / z 12$ $\left(\mathrm{C}^{+}\right), \mathrm{HCl}^{+}$signal at $m / z 36\left(\mathrm{C}_{3}^{+}\right), \mathrm{SO}^{+}$signal at $m / z 48$ $\left(\mathrm{C}_{4}^{+}\right), \mathrm{C}_{2} \mathrm{H}_{4} \mathrm{O}_{2}^{+}$signal at $m / z 60\left(\mathrm{C}_{5}^{+}\right)$. It also should be noted that, although the AMS is able to capture the bulk of atmospheric accumulation mode particles (Canagaratna et al., 2007), the right side of size distributions may be affected by the incomplete transmission of larger particles limited by the SP-AMS inlet (in particular, the supermicron ones).

As can be expected, all inorganic species (sulfate, nitrate, chloride, and ammonium) display a unimodal distribution with an accumulation mode peaking $\sim 550 \mathrm{~nm}$ (vacuum aerodynamic diameter, $D_{\text {va }}$; DeCarlo et al., 2004), since they were mainly formed from secondary reactions. The organics has a much broader size distribution across from ultrafine $(<100 \mathrm{~nm})$ to supermicron meter range, with a small sub-peak centering $\sim 120 \mathrm{~nm}$ in addition to the major peak at $\sim 440 \mathrm{~nm}$, indicating influences from both primary and secondary emissions. On the contrary, size distribution of $r \mathrm{BC}$ behaves very differently from other components, which peaks at 90-200 nm range, reflecting clearly that it mainly originates from primary emissions. Overall, the small particles predominantly consist of organics and $r \mathrm{BC}$, which together account for more than $90 \%$ of the ultrafine particle 

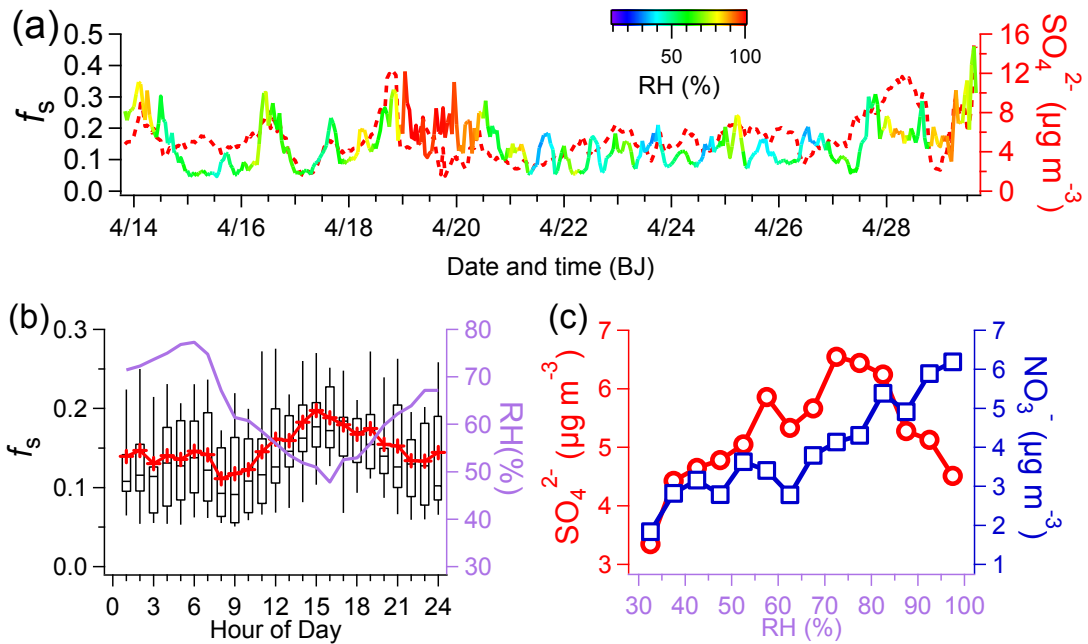

Figure 4. Time series of (a) sulfur oxidation ratio, $f_{\mathrm{S}}=n \mathrm{SO}_{4}^{2-} /\left(n \mathrm{SO}_{4}^{2-}+n \mathrm{SO}_{2}\right)$, and sulfate; (b) diurnal variations of $f_{\mathrm{S}}$ and $\mathrm{RH}$ (the lines and cross symbols indicate the mean values, the lines in the boxes indicate the median values, the upper and lower boundaries of the boxes indicate the 75 th and 25 th percentiles, and the whiskers above and below the boxes indicate the 90th and 10th percentiles); (c) sulfate and nitrate concentrations vs. $\mathrm{RH}$, the circles or squares represent the average concentrations within different $\mathrm{RH}$ bins (5\% increment) for sulfate and nitrate, respectively.
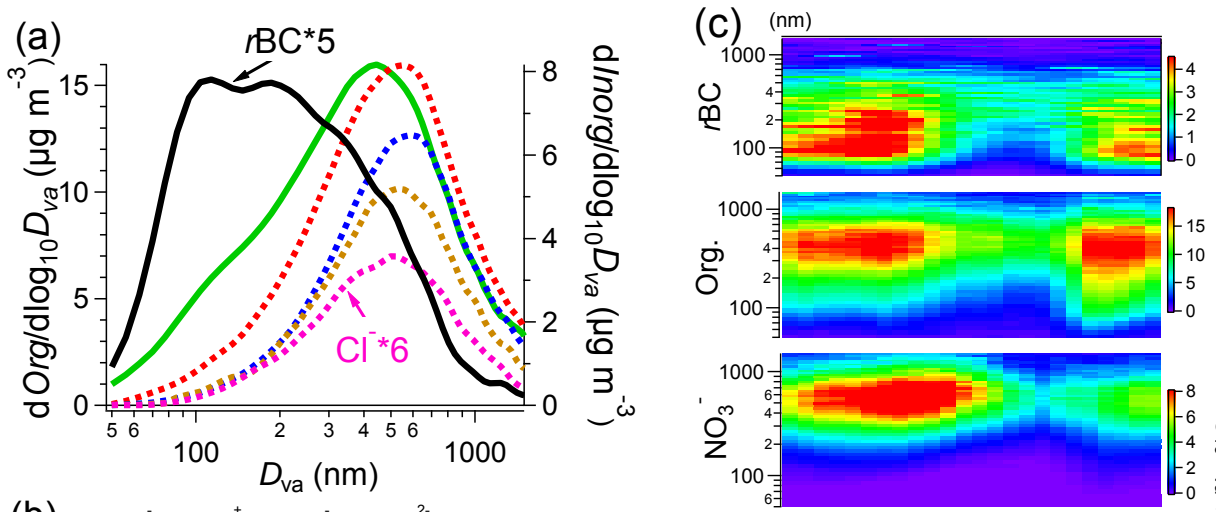

(b) $\square \mathrm{Cl}^{-}=\mathrm{NH}_{4}^{+}=\mathrm{NO}_{3}^{-}=\mathrm{SO}_{4}^{2-}=r \mathrm{BC}=$ Organics
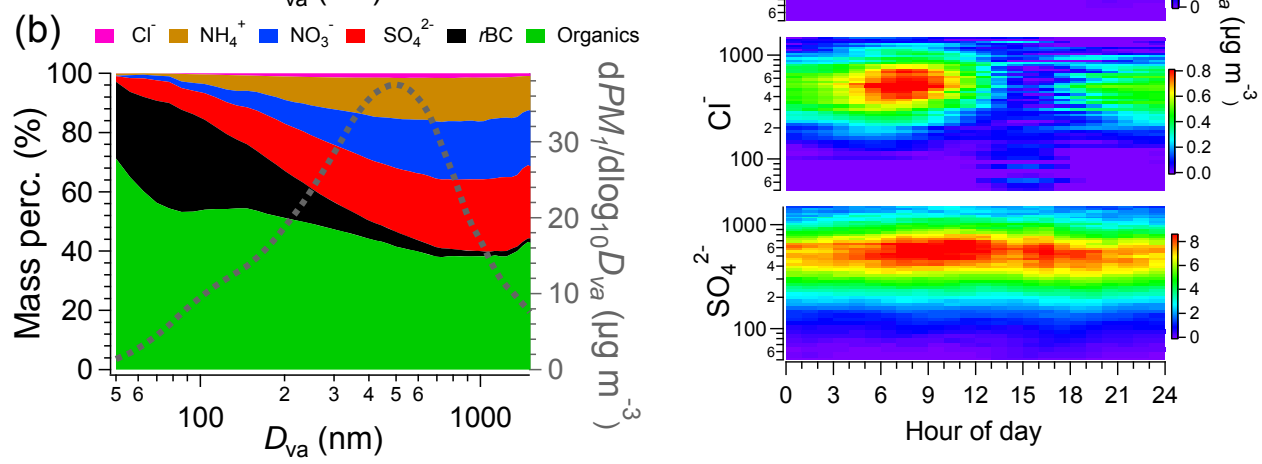

Figure 5. (a) Mass-based average size distributions of organics, $r \mathrm{BC}$ (left $y$ axis), sulfate, nitrate, chloride, and ammonium (right $y$ axis) ( $D_{\mathrm{va}}$, vacuum aerodynamic diameter), (b) fractional contributions of the six $\mathrm{PM}_{1}$ species as a function of particle size (left $y$ axis), and size distribution of total $\mathrm{PM}_{1}$ (right $y$ axis), (c) diurnal profiles of the size distributions of $r \mathrm{BC}$, organics, nitrate, chloride, and sulfate. 
mass. Mass contributions from inorganic species increase significantly with the increase of particle size, and they dominate masses of particles larger than $400 \mathrm{~nm}$ (Fig. 5b).

In line with the diurnal mass loadings of the $\mathrm{PM}_{1}$ species shown in Fig. 2c, the diurnal size distribution of sulfate is generally stable, with masses concentrating in the 400$700 \mathrm{~nm}$ range throughout the day (Fig. 5c); while the size distributions of nitrate, chloride, and organics present clear enhancements in the 300-700 nm range during early morning and early evening due to increased mass concentrations of these species during these two periods. The size distribution of $r \mathrm{BC}$ is also enhanced during the morning and evening hours, but it extends to a much smaller size range $(<100 \mathrm{~nm})$.

\section{3 $\mathrm{PM}_{1}$ contributions on visibility impairment}

In order to figure out the major species that are responsible for the visibility degradation, here we employed the IMPROVE method to reconstruct the light extinction coefficients $\left(b_{\text {ext }}\right) . b_{\text {ext }}$ values are derived from the measured visibility: $b_{\text {ext }}=3.91 / V_{s}$ (Kong et al., 2015), where $V_{s}$ stands for the visibility (in meter). The following IMPROVE formula (Yang et al., 2007) was used:

$$
\begin{aligned}
b_{\text {ext }}= & 3 f(\mathrm{RH})\left\{\left[\left(\mathrm{NH}_{4}\right)_{2} \mathrm{SO}_{4}\right]+\left[\mathrm{NH}_{4} \mathrm{NO}_{3}\right]+\left[\mathrm{NH}_{4} \mathrm{Cl}\right]\right\} \\
& +4[\mathrm{OM}]+10[\mathrm{BC}]+1[\text { soil }]+10
\end{aligned}
$$

where $f(\mathrm{RH})$ is a $\mathrm{RH}$-dependent empirical coefficient which considers the effects of water uptake by inorganic salts on the light extinction; the $f(\mathrm{RH})$ values used here were taken from Malm and Day (2001), which were regressed from the Great Smoky data set. [ $\left.\left(\mathrm{NH}_{4}\right)_{2} \mathrm{SO}_{4}\right],\left[\mathrm{NH}_{4} \mathrm{NO}_{3}\right],\left[\mathrm{NH}_{4} \mathrm{Cl}\right],[\mathrm{OM}]$, and $[\mathrm{BC}]$ represent the mass concentrations of ammonium sulfate, ammonium nitrate, ammonium chloride, organics and black carbon directly from the SP-AMS measurements (in $\left.\mu \mathrm{g} \mathrm{m}^{-3}\right)\left(\left[\left(\mathrm{NH}_{4}\right)_{2} \mathrm{SO}_{4}\right]=1.375 \times\left[\mathrm{SO}_{4}^{2-}\right],\left[\mathrm{NH}_{4} \mathrm{NO}_{3}\right]=\right.$ $1.29 \times\left[\mathrm{NO}_{3}^{-}\right]$and $\left.\left[\mathrm{NH}_{4} \mathrm{Cl}\right]=1.51 \times\left[\mathrm{Cl}^{-}\right]\right)$. Since the SPAMS cannot accurately measure soil components (e.g., various metals/metal oxides/metal salts), the term [soil] was set to zero during calculations.

By using this method, the reconstructed visibilities match reasonably well with the measured values $\left(r^{2}=0.50\right)$ as shown in Fig. 6a. Figure $6 \mathrm{~b}$ shows the time series of the measured and reconstructed extinction coefficients throughout the whole sampling period. It should be noted that, on average, the measured $\mathrm{PM}_{1}$ species are only able to explain $\sim 44 \%$ of the light extinction. This is likely due to that (1) as shown earlier, the SP-AMS measured $\mathrm{PM}_{1}$ only occupies $\sim 54 \%$ of the $\mathrm{PM}_{2.5}$ mass; (2) we did not include contributions from soil components, coarse particles and also some gas-phase species (such as $\mathrm{NO}_{2}$ ); (3) although the influences of water are partly included through $f(\mathrm{RH})$ for inorganic salts, the water uptake by organic species are not considered explicitly, which can be significant especially for the SOA under high RH conditions (Duplissy et al., 2011; Denjean et al., 2015). Indeed, as shown in Fig. 6a, reconstructed visibilities appear to deviate more significantly from the measured visibilities under high RH than ones under low RH conditions, suggesting the importance of particle-bounded water on visibility degradation. The pie chart in Fig. $6 \mathrm{~b}$ presents the average relative contributions of different components to the light extinction of $\mathrm{PM}_{1}$. The largest contributor is organics which accounts for $37.7 \%$, followed by ammonium sulfate $(25.1 \%), r \mathrm{BC}(20.7 \%)$, ammonium nitrate $(15.1 \%)$ and a minor contributor of ammonium chloride $(1.4 \%)$.

\subsection{Chemical characteristics of $\mathrm{OA}$}

The unique laser vaporizer of SP-AMS allows it to detect $r \mathrm{BC}$ and species coated on the $r \mathrm{BC}$ core including both nonrefractory and refractory organics; thus comparison between the OA mass spectra obtained with dual vaporizers and Tungsten vaporizer settings can infer some information regarding the chemical features of refractory organics, which were unable to be determined by any other types of AMS. As shown in Fig. $7 \mathrm{a}$ and $\mathrm{b}$, the OA obtained with the dual-vaporizers setting have slightly higher oxygen-to-carbon $(\mathrm{O} / \mathrm{C})$ ratio $(0.28$ vs. 0.27$)$, nitrogen-to-carbon $(\mathrm{N} / \mathrm{C})$ ratio $(0.033$ vs. $0.032)$ and lower hydrogen-to-carbon $(\mathrm{H} / \mathrm{C})$ ratio (1.50 vs. 1.52) than the corresponding elemental ratios of OA obtained with the Tungsten vaporizer only. This result indicates that refractory organics are likely more oxygenated than the nonrefractory organics, and for this data set it is mainly due to a higher fractional contribution from $\mathrm{C}_{2} \mathrm{H}_{3} \mathrm{O}^{+}$(see the inset of Fig. 7a). This is different from the results on laboratorygenerated nascent soot, where larger $f \mathrm{CO}_{2}^{+}$(i.e., the fraction of total organic signal contributed by $\mathrm{CO}_{2}^{+}$) was observed with the dual-vaporizers setting, indicating the variability of the chemical compositions of refractory organics.

It should be noted that, accurate determination of refractory organics is very difficult because: (1) a large portion of refractory organics cannot be detected by the SP-AMS if they did not coat on $r \mathrm{BC}$ cores; (2) to accurately measure the species only coated on $r \mathrm{BC}$ cores, the Tungsten vaporizer has to be physically removed, otherwise the vaporizer temperature is still around $150^{\circ} \mathrm{C}$ even its power is turned off, and the non-refractory organics that do not coat on $r \mathrm{BC}$ cores can still be measured and complicates the analyses; (3) the $\mathrm{CE}$ and IE values for different species may vary under different vaporizer settings, so that direct subtraction of organics measured under Tungsten-only setting from the organics measured under the dual-vaporizer setting may not represent the real refractory organics; (4) some ions measured under dual-vaporizer setting are likely induced by the laser itself rather than the $70 \mathrm{ev}$ electron impact. For example, a series of fullerene-like carbon clusters can be generated by the laser itself, even though they do not really exist in the atmosphere (J. Wang et al., 2016; Onasch et al., 2015). This laser-induced ion formation scheme may work for other organics, thus making it even more difficult for identifying the 

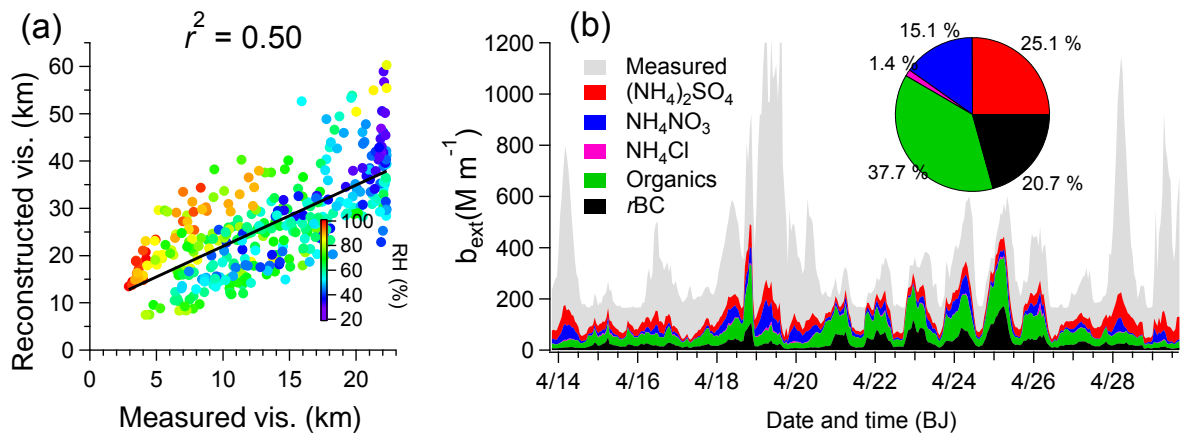

Figure 6. (a) Scatter plot of reconstructed vs. measured visibility (colored by RH), (b) light extinction coefficients derived from measured visibility (gray), and reconstructed from SP-AMS measured ammonium sulfate, ammonium nitrate, ammonium chloride, organics and $r$ BC using the IMPROVE method. The inset pie shows the relative contributions of the five species to the light extinction of $\mathrm{PM}_{1}$.
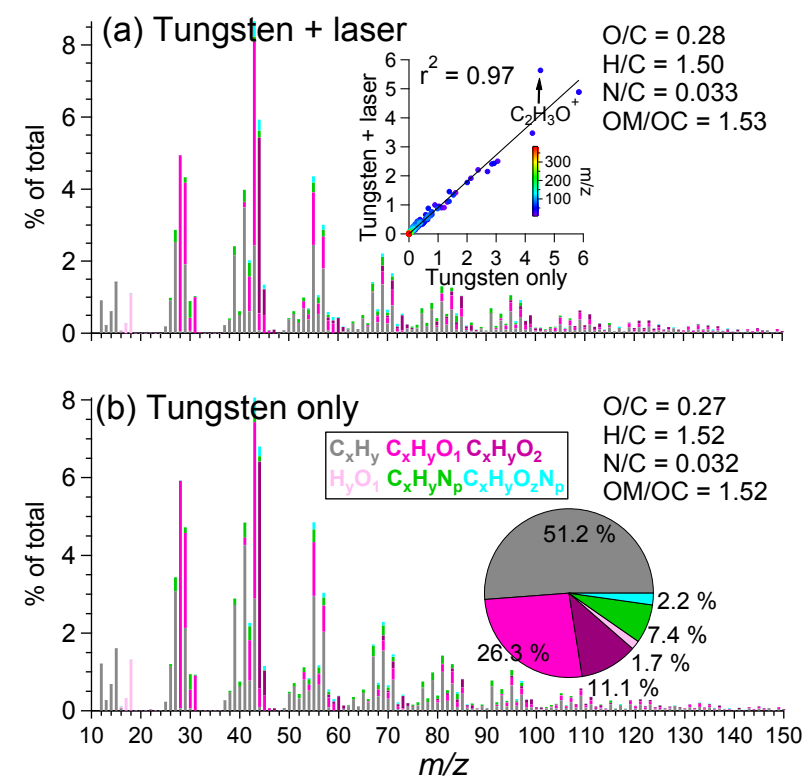

Figure 7. Campaign-averaged high-resolution mass spectra of OA colored by six ion categories, in the case of (a) dual vaporizers (Tungsten + laser) (the inset scatter plot compares the spectral similarity between panels $\mathbf{a}$ and $\mathbf{b}$ ), and (b) Tungsten vaporizer only (the inset pie shows the relative contributions of six ion categories to the total OA).

refractory organics. Further studies are essential to investigate this issue.

Overall, the $\mathrm{O} / \mathrm{C}$ ratio $(0.27)$ of $\mathrm{OA}$ in Nanjing during springtime is a bit lower than those observed at other urban locations in China - for instances, 0.30 in Shenzhen (He et al., 2011), 0.31 in Shanghai (Huang et al., 2012), 0.33 in Lanzhou (Xu et al., 2014) and 0.34 in Beijing (Zhang et al., 2014), and much lower than those at rural sites - for instances, 0.47 in Kaiping (Huang et al., 2011) and 0.59 in Changdao (Hu et al., 2013). As O / C ratio is a good indicator of the aging degree of $\mathrm{OA}$, the relatively low $\mathrm{O} / \mathrm{C}$ level indicates a significant contribution from fresh emissions in Nanjing aerosols during springtime. Accordingly, the non-refractory OA (pie chart in Fig. 7b) is dominated by hydrocarbon $\mathrm{C}_{x} \mathrm{H}_{y}^{+}$ions $(51.2 \%)$ rather than the oxygencontaining ion fragments (37.4\% of $\mathrm{C}_{x} \mathrm{H}_{y} \mathrm{O}_{1}^{+}$and $\mathrm{C}_{x} \mathrm{H}_{y} \mathrm{O}_{2}^{+}$).

The scatter plot of $f_{44}$ (mass fraction of $m / z 44$ to the total OA) vs. $f_{43}$ (mass fraction of $\mathrm{m} / z, 43$ to the total OA) (a.k.a., triangle plot) (Ng et al., 2010) was often used to investigate the oxidation degrees of OA. As presented in Fig. 8, most OA reside in the bottom end of the triangular region, again pointing out the less-oxygenated behavior of the OA. Since the HRMS can separate different ions at the nominal $m / z$, we also examined the $f \mathrm{CO}_{2}^{+}$vs. $f \mathrm{C}_{2} \mathrm{H}_{3} \mathrm{O}^{+}$space and illustrated it in Fig. S9 - many OA locate outside the triangular region, yet still close to the bottom. Moreover, $\mathrm{m} / \mathrm{z} 60$ (mainly $\mathrm{C}_{2} \mathrm{H}_{4} \mathrm{O}_{2}^{+}$) is a significant fragment ion of levoglucosan, which is well known as the biomass burning aerosol tracer (Alfarra et al., 2007). However, as $f_{60}$ (mass fraction of $m / z 60$ to the total OA) is very low in OA (average $\pm 1 \sigma=0.4 \pm 0.06 \%$ ), indicating no biomass burning influences on the OA properties during springtime in Nanjing.

\subsection{Sources and evolution processes of $\mathrm{OA}$}

In order to further elucidate the sources and evolution processes of OA, we performed PMF analyses and identified four OA components, including two primary OA (POA) factors - a traffic-related hydrocarbon-like OA (HOA) and a cooking-related OA (COA), and two secondary OA factors a semi-volatile oxygenated OA (SV-OOA) and a low volatility OOA (LV-OOA). Details about their characteristics are discussed below.

\subsubsection{Mass spectral features of the $\mathrm{OA}$ factors}

The mass spectral profiles, time-dependent mass concentrations of the four OA factors and corresponding tracer ions are presented in Fig. 9. The HOA mass spectrum is dominated by the $\mathrm{C}_{x} \mathrm{H}_{y}^{+}$ions $\left(73.2 \%\right.$ ), such as $\mathrm{C}_{3} \mathrm{H}_{7}^{+}, \mathrm{C}_{4} \mathrm{H}_{7}^{+}, \mathrm{C}_{4} \mathrm{H}_{9}^{+}$, 


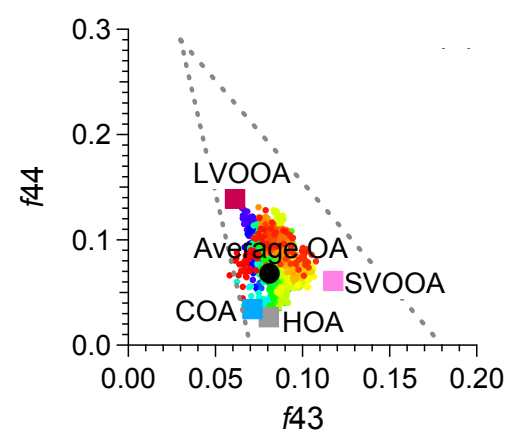

Figure 8. Triangle plot of $f_{44}$ vs. $f_{43}$ for all OA (colored by time), and the four OA factors identified by the PMF analyses.

$\mathrm{C}_{5} \mathrm{H}_{9}^{+}$etc., which are most likely produced from alkanes and cycloalkanes emitted from fuel and lubricating oil burning (Canagaratna et al., 2004). This feature is in good agreement with the mass spectral features of POA directly from vehicle emissions (Collier et al., 2015), and the HOA factors determined in many other locations (e.g., Ge et al., 2012b; Huang et al., 2010; Sun et al., 2011). HOA has the lowest O / C ratio (0.10) and highest $\mathrm{H} / \mathrm{C}$ ratio (1.75) among all factors, representing its behavior as primary fresh emissions. The COA mass spectrum is also rich in $\mathrm{C}_{x} \mathrm{H}_{y}^{+}$ions $(64.7 \%)$, but having more oxygenated ions $\left(\mathrm{C}_{x} \mathrm{H}_{y} \mathrm{O}_{z}^{+}\right)$than the $\mathrm{HOA}(26.5$ vs. $15.4 \%$ ), especially $\mathrm{C}_{3} \mathrm{H}_{3} \mathrm{O}^{+}$and $\mathrm{C}_{3} \mathrm{H}_{5} \mathrm{O}^{+}$ions. The significant contributions of $\mathrm{C}_{3} \mathrm{H}_{3} \mathrm{O}^{+}$and $\mathrm{C}_{3} \mathrm{H}_{5} \mathrm{O}^{+}$to $m / z 55$ and $m / z 57$ are a common feature of COA, that has been reported in various urban locations around the world, for example, Beijing (Sun et al., 2015a), London (Allan et al., 2010), Fresno (Ge et al., 2012b), New York City (Sun et al., 2011), and Barcelona (Mohr et al., 2012, 2015). These oxygen-containing ions are partly generated from the fragmentation of fatty acids in the cooking aerosols (Ge et al., $2012 \mathrm{~b}$ ). As a result, $\mathrm{COA}$ has a higher $\mathrm{O} / \mathrm{C}$ ratio of 0.16 and a lower $\mathrm{H} / \mathrm{C}$ ratio of 1.67 than those of HOA. The $\mathrm{O} / \mathrm{C}$ and $\mathrm{H} / \mathrm{C}$ levels of COA in this work are also close to those identified in other previously mentioned locations. The consistency of the chemical characteristics of COA from such different locations suggests that ambient COA is more relevant to the cooking oil rather than the different types of food, which was postulated earlier by Allan et al. (2010).

Unlike the two POA factors, SV-OOA and LV-OOA are both abundant in oxygen-containing fragments $\left(\mathrm{C}_{x} \mathrm{H}_{y} \mathrm{O}_{z}^{+}\right.$ ions), which are 46.4 and $54.8 \%$, respectively. The higher $\mathrm{O} / \mathrm{C}$ ratio ( 0.55 vs. 0.32$)$ and more $\mathrm{C}_{x} \mathrm{H}_{y} \mathrm{O}_{2}^{+}$ions (18.8 vs. $11.8 \%$ ) in the LV-OOA mass spectrum than those of the SVOOA, reflecting the fact that LV-OOA went through more aging/oxidation reactions than SV-OOA. The O / C ratio of SVOOA is 0.32 , which is within the $\mathrm{O} / \mathrm{C}$ range of SV-OOA observed worldwide (Jimenez et al., 2009). The LV-OOA O / C ratio of 0.55 is in the lower end compared to the $\mathrm{O} / \mathrm{C}$ levels of LV-OOA observed in other China sites, for example, 0.64 in Kaiping (Huang et al., 2011), 0.65 in Shanghai (Huang et al., 2012), 0.68 in Lanzhou (Xu et al., 2014), 0.78 in Changdao (Hu et al., 2013), and 0.80 in Hong Kong (Lee et al., 2013).

Consistently, in the $f_{44}$ vs. $f_{43}$ space (Fig. 8), SV-OOA situates near the bottom side while LV-OOA approaches to the upper part of the triangular region because of a much larger fractional contribution of $\mathrm{CO}_{2}^{+}$in the LV-OOA mass spectrum. HOA and COA, as POA factors, both reside in the bottom end of the plot, away from SV-OOA and LV-OOA; while they locate outside the triangle in the $f \mathrm{CO}_{2}^{+}$vs. $f \mathrm{C}_{2} \mathrm{H}_{3} \mathrm{O}^{+}$ space (Fig. S9), indicating that the HRMS acquired by the SP-AMS is better in differentiating POA factors from other SOA factors than the unit mass resolution (UMR) data.

In order to justify the OA factors identified in this study, we compared the spectral similarities of the OA factor spectral profiles (in both HR and UMR) with those separated during wintertime in Beijing (Sun et al., 2015a), summertime in Lanzhou (Xu et al., 2014), and wintertime in Fresno (Ge et al., 2012b, a). The results are listed in Table 1. Indeed, the HOA, COA, and LV-OOA mass spectra are highly similar to the corresponding factors identified in Bejing, Lanzhou, and Fresno $\left(r^{2}>0.87\right)$; SV-OOA also correlates fairly well with Bejing and Lanzhou SV-OOA too, but with relative low $r^{2}(0.68-0.75)$, mainly because of one or two ion fragments, namely, higher $\mathrm{CO}^{+}$and $\mathrm{CO}_{2}^{+}$signals in Beijing SV-OOA and higher $\mathrm{C}_{2} \mathrm{H}_{3} \mathrm{O}^{+}$signal in Lanzhou SV-OOA than those in Nanjing SV-OOA. The SV-OOA on the other hand, correlates very well with the Fresno OOA $\left(r^{2}=0.90\right.$ and 0.91$)$.

Moreover, as presented in Fig. 9a, the HOA mass spectrum contains relatively higher fraction of ions with large $m / z$ values $(m / z>100)$ than that of COA $(14.0$ vs. $8.2 \%)$, and most of these ions are $\mathrm{C}_{x} \mathrm{H}_{y}^{+}$ions, probably from fuel-burningemitted long-chain alkanes, etc. The SV-OOA also includes more large $m / z$ ion fragments $(m / z>100)$ than those in the LV-OOA mass spectrum (10.5 vs. $5.3 \%$ ), likely suggesting that further oxidation of SOA species may lead to the fragmentation of high molecular weight species and formation of small molecules - a mechanism verified by both lab-scale experiments (e.g., Yu et al., 2014) and field measurements (e.g., Lee et al., 2012).

\subsubsection{Temporal variations, diurnal patterns, and relative contributions of the $\mathrm{OA}$ factors}

The temporal variations of different $\mathrm{OA}$ factors and their corresponding tracer ions are displayed in Fig. 9 b. $\mathrm{C}_{4} \mathrm{H}_{9}^{+}$ion, a.k.a., the HOA mass spectral tracer (Zhang et al., 2005) indeed varies very closely to the HOA $\left(r^{2}=0.94\right)$. Time series of the $\mathrm{COA}$ tracer ion $\mathrm{C}_{6} \mathrm{H}_{10} \mathrm{O}^{+}$(and also $\mathrm{C}_{5} \mathrm{H}_{8} \mathrm{O}^{+}$, $\mathrm{C}_{7} \mathrm{H}_{12} \mathrm{O}^{+}$) (Sun et al., 2011; Ge et al., 2012b) match very well with that of COA too $\left(r^{2}=0.90\right)$. SV-OOA correlates better with $\mathrm{C}_{2} \mathrm{H}_{3} \mathrm{O}^{+}\left(r^{2}=0.90\right)$ than with $\mathrm{CO}_{2}^{+}\left(r^{2}=0.66\right)$. Although LV-OOA does not correlate very well with $\mathrm{CO}_{2}^{+}$ $\left(r^{2}=0.12\right)$ mainly due to the mismatch during 23-26 April, the correlation is still much better than it with $\mathrm{C}_{2} \mathrm{H}_{3} \mathrm{O}^{+}$ 

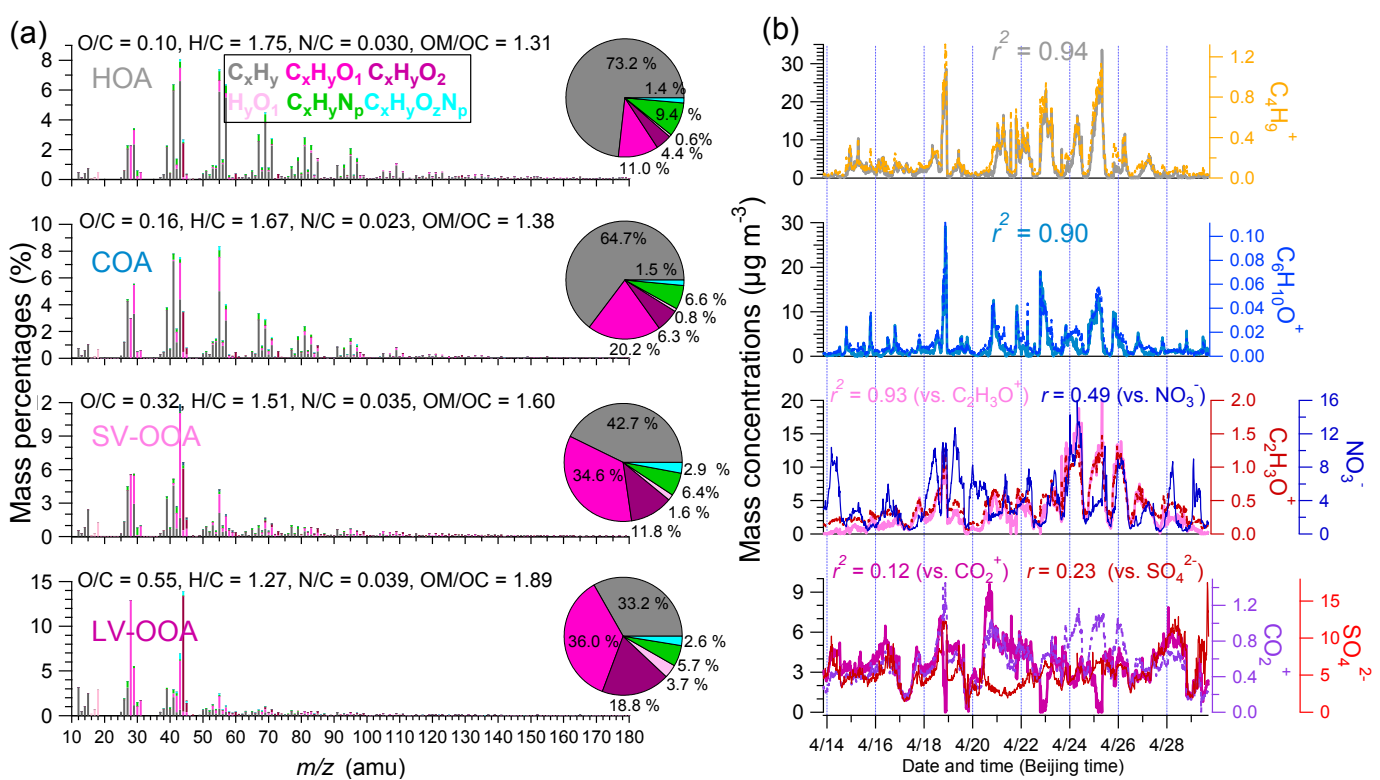

Figure 9. (a) High-resolution mass spectra of hydrocarbon-like OA (HOA), cooking-related OA (COA), semi-volatile oxygenated OA (SVOOA), and low volatility oxygenated OA (LV-OOA) colored by six ion categories (the four inset pies show the relative contributions of the six ion categories to the four OA factors, respectively), (b) time series of the four OA factors, corresponding tracer ions, nitrate and sulfate.

Table 1. Correlation coefficients (Pearson's $r^{2}$ ) between the mass spectral profiles of the OA factors identified in this work with the corresponding factors identified in Beijing (2013 winter) (Sun et al., 2015a), Lanzhou (2014 summer) (Xu et al., 2014), and Fresno (2010 winter) (Ge et al., 2012b).

\begin{tabular}{lrcr}
\hline \multirow{2}{*}{ Nanjing } & \multicolumn{3}{c}{ High-resolution MS $\left(r^{2}\right)$} \\
\cline { 2 - 4 } (2015 spring) & $\begin{array}{r}\text { Beijing } \\
\text { (2013 winter) }\end{array}$ & $\begin{array}{r}\text { Lanzhou } \\
(2012 \text { summer })\end{array}$ & $\begin{array}{r}\text { Fresno } \\
(2010 \text { winter })^{*}\end{array}$ \\
\hline HOA & 0.92 & 0.90 & 0.98 \\
COA & 0.93 & 0.94 & 0.93 \\
SV-OOA & 0.68 & 0.75 & 0.90 \\
LV-OOA & 0.91 & 0.98 & 0.87 \\
\hline & Unit mass resolution MS $\left(r^{2}\right)$ & \\
\hline HOA & 0.92 & 0.91 & 0.99 \\
COA & 0.96 & 0.96 & 0.95 \\
SV-OOA & 0.70 & 0.74 & 0.91 \\
LV-OOA & 0.90 & 0.98 & 0.89 \\
\hline
\end{tabular}

* Note the Fresno (2010 winter) study only identified one OOA factor, we thus compared both SV-OOA and LV-OOA in this study with it.

$\left(r^{2}<0.001\right)$. In Table 2, we tabulate the correlation coefficients $(r)$ of the four OA factors with the gas-phase species, $\mathrm{BC}$ and inorganic species. Note we used Pearson's $r$ not $r^{2}$ here since some correlation coefficients are negative. From the table, it is clear that the traffic-related gaseous species, $\mathrm{CO}$ and $\mathrm{NO}_{2}$, correlate best with HOA among all OA factors; SV-OOA correlates better with nitrate $(r=0.49)$ than it with sulfate $(r=0.11)$; LV-OOA correlate better with sulfate $(r=0.23)$ that it with nitrate $(r=0.11)$. All these results are consistent with the traffic origin of HOA, the semi-volatile and low-volatility behaviors of SV-OOA and LV-OOA.

Accordingly, diurnal cycles of the OA factors are presented in Fig. 10a. Correlation coefficients $(r)$ of the diurnal variations between OA factors with gas-phase species and inorganic species are provided in Table 2, as well. HOA concentrations show an early morning peak, and it remains at high levels during nighttime. Besides the impacts of boundary layer height, this is also due to enhanced emissions from construction vehicles around the site, which were in fact 
Table 2. Correlation coefficients (Pearson's $r$ ) between the time series of the four OA factors with the gas-phase species (hourly data) and other $\mathrm{PM}_{1}$ components ( $15 \mathrm{~min}$ data), and the correlation coefficients between the diurnal data (values in italic are significant ones and are discussed in details in the text ).

\begin{tabular}{|c|c|c|c|c|c|c|c|c|c|}
\hline Pearson's $r$ & Temp. $(T)$ & $\mathrm{CO}$ & $\mathrm{NO}_{2}$ & $\mathrm{SO}_{2}$ & $\mathrm{O}_{3}$ & $\mathrm{SO}_{4}^{2-}$ & $\mathrm{NO}_{3}^{-}$ & $\mathrm{Cl}^{-}$ & $r \mathrm{BC}$ \\
\hline & \multicolumn{5}{|c|}{ Hourly data } & \multicolumn{4}{|c|}{$15 \mathrm{~min}$ data } \\
\hline HOA & -0.14 & 0.71 & 0.77 & 0.13 & -0.54 & 0.15 & 0.26 & 0.45 & 0.92 \\
\hline $\mathrm{COA}$ & 0.11 & 0.50 & 0.58 & -0.06 & -0.22 & 0.19 & 0.07 & 0.08 & 0.61 \\
\hline SVOOA & 0.19 & 0.41 & 0.70 & 0.14 & -0.21 & 0.11 & 0.49 & 0.25 & 0.70 \\
\hline \multirow[t]{2}{*}{ LVOOA } & 0.069 & -0.2 & -0.18 & 0.06 & 0.14 & 0.23 & 0.11 & 0.01 & -0.22 \\
\hline & \multicolumn{9}{|c|}{ Diurnal data } \\
\hline HOA & -0.94 & 0.86 & 0.86 & 0.66 & -0.96 & -0.35 & 0.72 & 0.82 & 0.99 \\
\hline $\mathrm{COA}$ & -0.15 & 0.28 & 0.59 & -0.24 & -0.24 & -0.57 & -0.33 & -0.25 & 0.19 \\
\hline SVOOA & -0.85 & 0.86 & 0.94 & 0.58 & -0.90 & -0.51 & 0.53 & 0.61 & 0.89 \\
\hline LVOOA & 0.76 & -0.58 & -0.83 & -0.27 & 0.77 & 0.72 & -0.26 & -0.33 & -0.75 \\
\hline
\end{tabular}

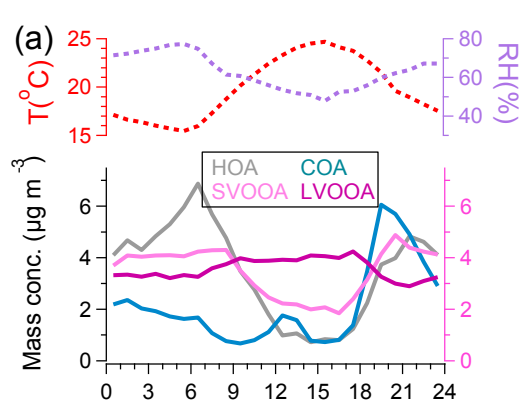

(c) Organics $12.7 \mu \mathrm{g} \mathrm{m}^{-3}$
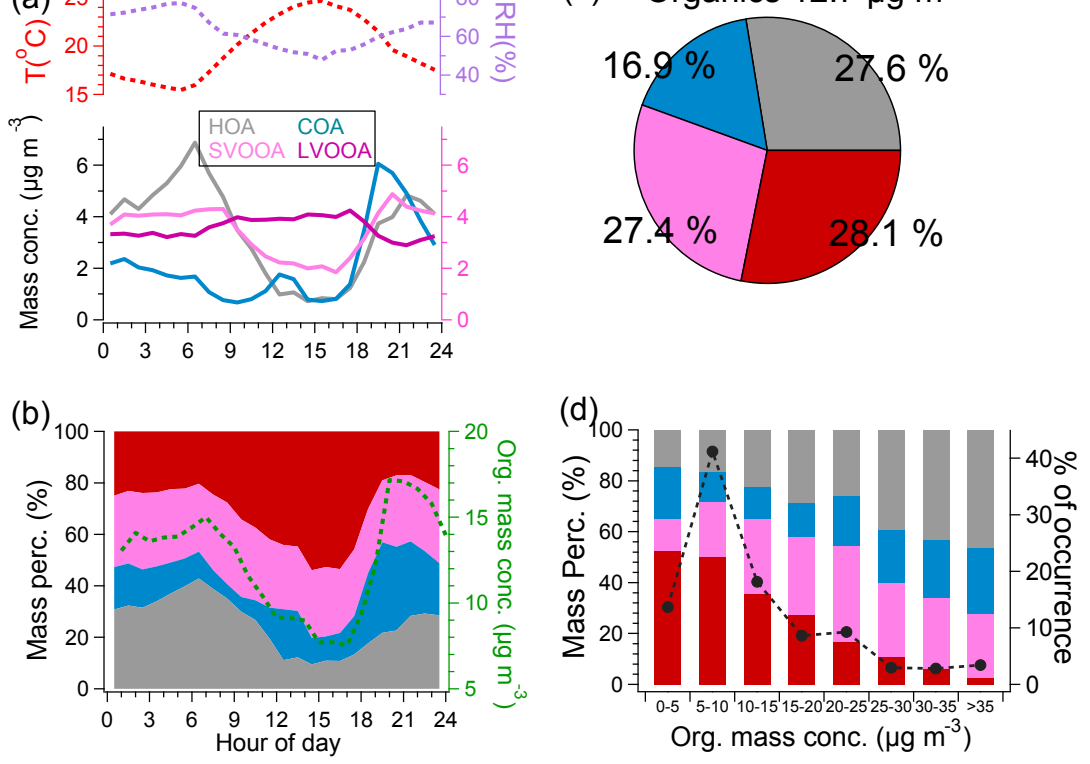

Figure 10. (a) Diurnal cycles of mass concentrations of the four OA factors (bottom panel), temperature (top panel, left $y$ axis) and RH (top panel, right $y$ axis), (b) diurnal variations of mass contributions of the four OA factors (left $y$ axis), and the total OA mass concentrations (right $y$ axis), (c) campaign-averaged mass contributions of the four OA factors to the total OA mass, and (d) mass contributions of the four OA factors (left $y$ axis), and the fractions of the number of data points to the total number of data points for the OA at different concentration ranges (right $y$ axis).

much more active during nighttime than during daytime because of the restrictions of Nanjing government. Most of those vehicles used low-quality diesel fuel, and could emit a large amount of $r \mathrm{BC}$ particles. The $r \mathrm{BC}$ diurnal pattern is indeed almost identical to that of HOA $(r=0.99)$, indicating that the HOA during this campaign was apparently associated with the construction vehicle emissions. COA concentrations increase during noon $(12 \mathrm{pm}-1 \mathrm{pm})$ and early evening, in response to lunchtime and dinnertime cooking activities. SV-OOA concentrations decreases from $9 \mathrm{am}$, and reach a minimum in the afternoon $(3 \mathrm{pm}-4 \mathrm{pm})$, opposite to the variation of temperatures $(r=-0.85)$ but similar to that of nitrate $(r=0.53)$, corroborating its semi-volatile feature. Different from other factors, LV-OOA concentrations increase during daytime and show positive correlation with temperature $(r=0.76)$; it also has negative correlation with the diurnal cycle of RH $(r=-0.75)$. Both behaviors are similar to those of sulfate ( $r=0.72$ for the diurnal cycle of LVOOA vs. sulfate), indicating the leading role of photochemical oxidation for LV-OOA formation as well. 


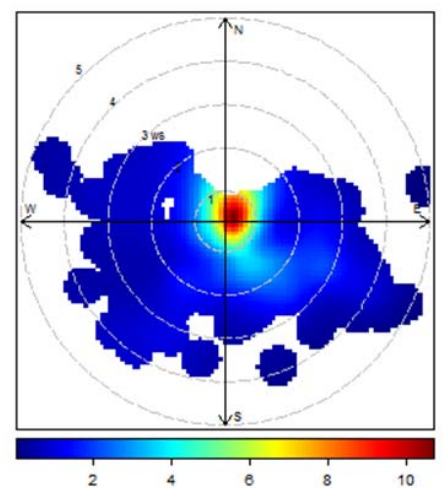

HOA $\left(\mu \mathrm{g} \mathrm{m}^{-3}\right)$

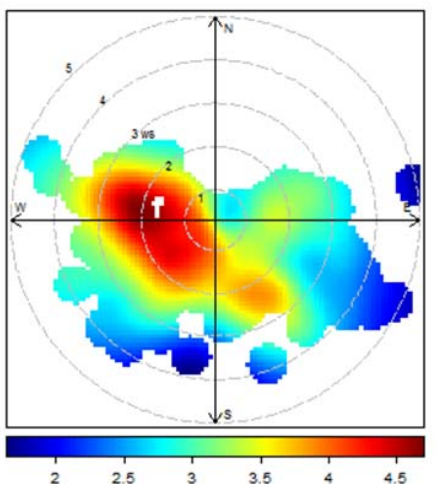

LV-OOA $\left(\mu \mathrm{g} \mathrm{m}^{-3}\right)$

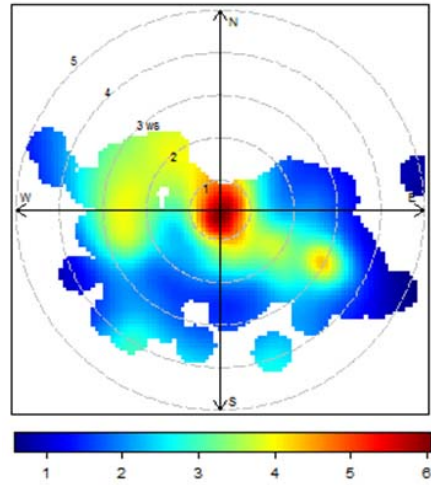

Nitrate $\left(\mu \mathrm{g} \mathrm{m}^{-3}\right)$
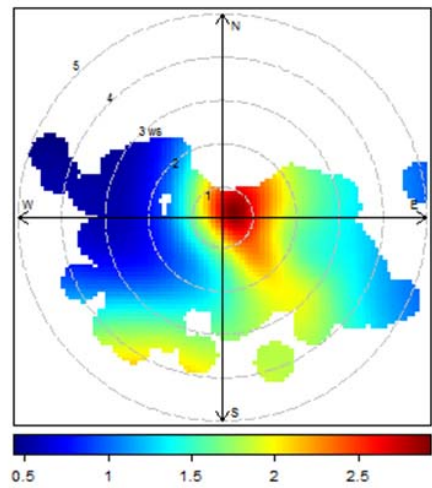

$\operatorname{COA}\left(\mu \mathrm{g} \mathrm{m}^{-3}\right)$

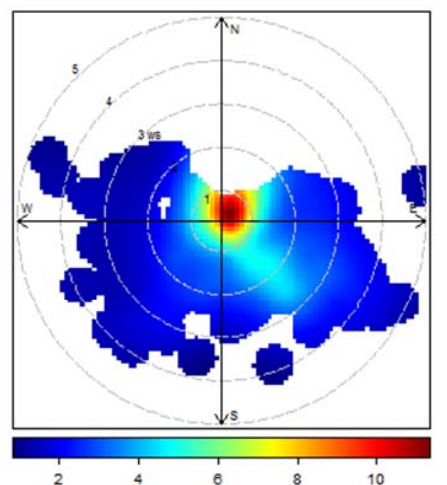

$r \mathrm{BC}\left(\mu \mathrm{g} \mathrm{m}^{-3}\right)$

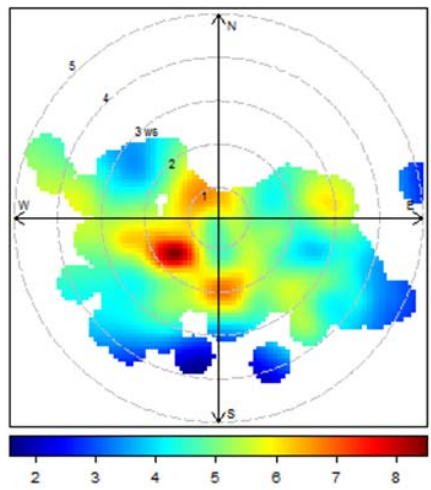

Sulfate $\left(\mu \mathrm{g} \mathrm{m}^{-3}\right)$

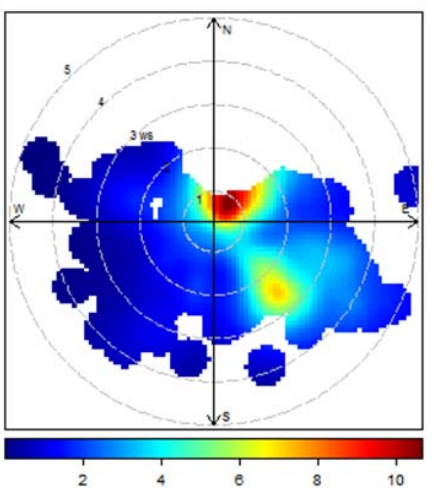

SV-OOA $\left(\mu \mathrm{g} \mathrm{m}^{-3}\right)$

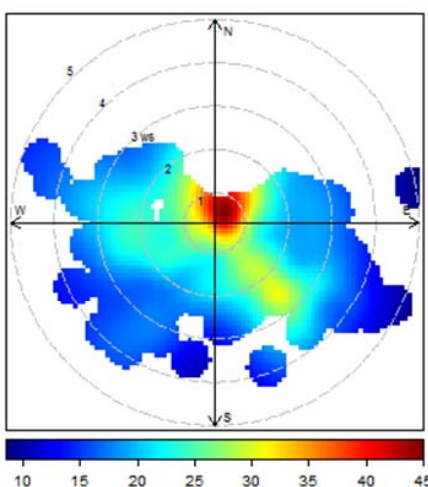

$\mathrm{PM}_{1}\left(\mu \mathrm{g} \mathrm{m}^{-3}\right)$

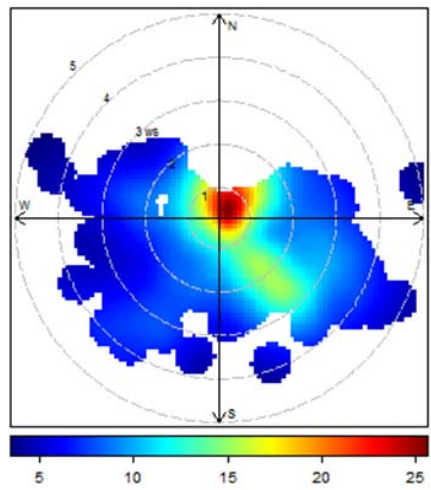

OA $\left(\mu \mathbf{g ~ m}^{-3}\right)$

Figure 11. Bivariate polar plots of HOA, COA, SV-OOA, LV-OOA, $r \mathrm{BC}, \mathrm{PM}_{1}$, nitrate, sulfate, and the total OA (the color scale shows the concentration of each species, and the radical scale shows the wind speed that increases outward from the center).

As shown in Fig. 10b, due to mainly the increase of LVOOA mass loading, OA is overwhelmingly dominated by the SOA (SV-OOA + LV-OOA) in the afternoon $(80.2 \%$ at $3 \mathrm{pm})$; $\mathrm{POA}(\mathrm{HOA}+\mathrm{COA})$ only dominates the OA mass during morning (53.2\% at $7 \mathrm{am})$ and early evening $(56.9 \%$ at $8 \mathrm{pm})$ in response to the enhanced traffic and cooking emissions. On average, the OA is composed of $27.6 \%$ of HOA,
$16.9 \%$ of COA, $27.4 \%$ of SV-OOA and $28.1 \%$ of LV-OOA (Fig. 10c), with SOA outweighing POA (55.5 vs. $44.5 \%$ ). However, as shown in Fig. 10d, with the increase of OA mass loadings, the fractional contribution of POA increases, highlighting the important and direct influences of anthropogenic emissions on the heavy pollution haze events. 

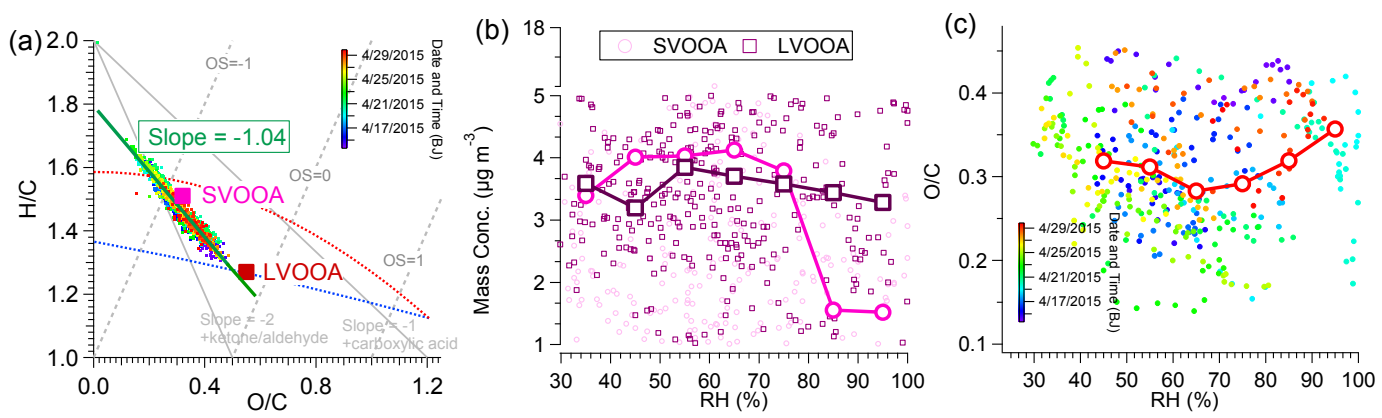

Figure 12. (a) Van Krevelen diagram of H / C vs. O / C ratios for all OA data colored by time, the blue and red dashed lines correspond to the right and left gray dashed lines in the $f_{44}$ vs. $f_{43}$ triangle plot of Fig. 8; the gray lines represent the addition of a particular functional group to an aliphatic carbon (Heald et al., 2010); (b) scatter plot of SVOOA and LVOOA mass concentrations vs. RH, the circles and squares represent the average mass concentrations within different RH bins (10\% increment) for SVOOA and LVOOA, respectively; (c) scatter plot of O / C vs. RH (colored by time), the circles represent the average O / C values within different RH bins (10\% increment).

\subsubsection{Local/regional influences and evolution processes of the OA factors}

Combining WS, WD and mass loadings, the bivariate polar plots of the four OA factors, $r \mathrm{BC}$, total $\mathrm{OA}$, nitrate, sulfate and the total $\mathrm{PM}_{1}$ are shown in Fig. 11. These plots provide an effective graphical method for showing the potential influences of air masses from different directions with different wind speeds to the receptor site (Carslaw and Beevers, 2013). Clearly, high mass loadings of HOA and $r$ BC mostly link with low WS $\left(<1 \mathrm{~m} \mathrm{~s}^{-1}\right)$, indicating they are mainly from local vehicle emissions. High COA concentrations occur mainly under low WS as well, but with some high concentrations accompanied with air masses from southeast under higher WS. SV-OOA appears to be mainly formed locally, except for a concentration hotspot in the southeast likely due to emissions from the tobacco factory that resides in that direction. Nitrate, as a semi-volatile species, behaves similarly to the SV-OOA. High concentrations of LV-OOA are distributed in all directions under higher WS, similar to that of sulfate, representing their regional behaviors. Overall, high $\mathrm{PM}_{1}$ mass loadings occur mainly under low WS, indicating that the $\mathrm{PM}_{1}$ is heavily affected by local emissions rather than pollutants in a regional scale.

The aging of OA can be described in general by the increase of $\mathrm{O} / \mathrm{C}$ and decrease of $\mathrm{H} / \mathrm{C}$. In this regard, we plotted the Van Krevelen diagram (Heald et al., 2010) (Fig. 12a) to show the relationships between $\mathrm{H} / \mathrm{C}$ and $\mathrm{O} / \mathrm{C}$ ratios for all OA as well as the four OA factors. Overall, in this study, the $\mathrm{H} / \mathrm{C}$ and $\mathrm{O} / \mathrm{C}$ ratios of OA data are correlated linearly with a slope of $-1.04\left(r^{2}=0.93\right)$. Interestingly, the two OOA factors lie very well on the fitted straight line. This trend may suggest that the evolution of secondary OA during this campaign follows a transformation pathway of SVOOA to LV-OOA. The diurnal cycle of LV-OOA is opposite to that of SV-OOA ( $r=-0.86)$, probably supporting this hypothesis. In addition, SV-OOA and LV-OOA mass concen- trations, and $\mathrm{O} / \mathrm{C}$ ratios of $\mathrm{OA}$ all show no obvious correlations with the RH as shown in Fig. 12b and c, indicating that aqueous-phase processing is insignificant compared to the photochemical processing for the oxidation of OA.

\section{Conclusions}

We present for the first time the real-time measurement results using the SP-AMS on submicron aerosols in urban Nanjing during springtime (13-29 April 2015). The dynamic variations of SP-AMS determined $\mathrm{PM}_{1}$ mass loadings, agreed well with the $\mathrm{PM}_{2.5}$ measured by the Met One $\mathrm{PM}_{2.5}$ analyzer. The average $\mathrm{PM}_{1}$ concentration was $28.2 \mu \mathrm{g} \mathrm{m}^{-3}$, lower than previous ACSM-determined $\mathrm{PM}_{1}$ concentrations during summer and winter in Nanjing. Organics on average comprised the largest fraction (45\%) of $\mathrm{PM}_{1}$, and its fractional contributions increased in the case of high $\mathrm{PM}_{1}$ mass loadings. The diurnal cycles of mass concentrations of organics, $r \mathrm{BC}$, nitrate, and chloride all exhibited a similar behavior, which was high in the early morning and evening, but low in the afternoon. Concentrations of sulfate, on the contrary, increased in the afternoon. Further investigations of $f_{\mathrm{S}}$, sulfate concentrations and its relationship with RH suggest that photochemical processing contributed significantly to sulfate formation compared to the aqueous-phase processing, while nitrate (and chloride) formation was mainly governed by the thermodynamic equilibrium. The chemically resolved mass-based size distribution data showed that $r \mathrm{BC}$ occupied a large fraction of ultrafine particles, while secondary inorganic species could dominate the mass of particles larger than $400 \mathrm{~nm}\left(D_{\mathrm{va}}\right)$. In addition, by using the IMPROVE method, we found that the observed $\mathrm{PM}_{1}$ components were able to reproduce $\sim 44 \%$ of the light extinction during this study.

PMF analyses resolved four OA factors, e.g., HOA, COA, SV-OOA and LV-OOA. Mass spectral profiles of these factors agree very well with the corresponding factors identified at other locations. The springtime OA showed no in- 
fluences from biomass burning emissions. On average, the OA is dominated by SOA $(55.5 \%)$, but POA appeared to be more important when the OA mass loadings are high, and can be dominant in the early morning and evening. Diurnal cycle of SV-OOA varied similarly to that of nitrate, reflecting its semi-volatile behavior. Diurnal variations of LV-OOA showed great resemblance to that of sulfate. The bivariate polar plots indicate that SV-OOA was formed locally, and the Van Krevelen diagram further suggests a transformation from SV-OOA to LV-OOA in Nanjing. Generally, our highly time-resolved SP-AMS measurement results may offer useful insights into the aerosol chemistry, and have important implications for the PM control and reduction in this densely populated region.

\section{Data availability}

The observational data in this study are available from the authors upon request (caxinra@163.com).

\section{The Supplement related to this article is available online at doi:10.5194/acp-16-9109-2016-supplement.}

Acknowledgements. This work was supported by the Natural Science Foundation of China (Grant Nos. 21407079 and 91544220), the Jiangsu Natural Science Foundation (BK20150042), the Jiangsu Provincial Specially-Appointed Professors Foundation, the LAPC Open Fund (LAPC-KF-2014-06), and the project funded by the Priority Academic Program Development of Jiangsu Higher Education Institutions (PAPD). M. Chen acknowledges the support from the Natural Science Foundation of China (Grant Nos. 21577065 and 91543115), the Commonweal Program of Environment Protection Department of China (201409027-05), and the International ST Cooperation Program of China (2014DFA90780). J. Wang also acknowledges the financial support from China Scholarship Council, and the innovative project for graduate student of Jiangsu Province. The authors thank Nanjing Environmental Monitoring Center for the supporting data, and the helps from Ling Li, Yanan He, Hui Chen and Yangzhou $\mathrm{Wu}$ during the campaign and preparation of the manuscript.

Edited by: I. Salma

Reviewed by: J. Chen and two anonymous referees

\section{References}

Aiken, A. C., Decarlo, P. F., Kroll, J. H., Worsnop, D. R., Huffman, J. A., Docherty, K. S., Ulbrich, I. M., Mohr, C., Kimmel, J. R., Sueper, D., Sun, Y., Zhang, Q., Trimborn, A., Northway, M., Ziemann, P. J., Canagaratna, M. R., Onasch, T. B., Alfarra, M. R., Prevot, A. S. H., Dommen, J., Duplissy, J., Metzger, A.,
Baltensperger, U., and Jimenez, J. L.: O / C and OM / OC ratios of primary, secondary, and ambient organic aerosols with high-resolution time-of-flight aerosol mass spectrometry, Environ. Sci. Technol., 42, 4478-4485, doi:10.1021/Es703009q, 2008.

Alfarra, M. R., Prevot, A. S. H., Szidat, S., Sandradewi, J., Weimer, S., Lanz, V. A., Schreiber, D., Mohr, M., and Baltensperger, U.: Identification of the Mass Spectral Signature of Organic Aerosols from Wood Burning Emissions, Environ. Sci. Technol., 41, 5770-5777, doi:10.1021/es062289b, 2007.

Allan, J. D., Williams, P. I., Morgan, W. T., Martin, C. L., Flynn, M. J., Lee, J., Nemitz, E., Phillips, G. J., Gallagher, M. W., and Coe, H.: Contributions from transport, solid fuel burning and cooking to primary organic aerosols in two UK cities, Atmos. Chem. Phys., 10, 647-668, doi:10.5194/acp-10-647-2010, 2010.

Canagaratna, M. R., Jayne, J. T., Ghertner, D. A., Herndon, S., Shi, Q., Jimenez, J. L., Silva, P. J., Williams, P., Lanni, T., Drewnick, F., Demerjian, K. L., Kolb, C. E., and Worsnop, D. R.: Chase studies of particulate emissions from in-use New York City vehicles, Aerosol Sci. Tech., 38, 555-573, doi:10.1080/02786820490465504, 2004.

Canagaratna, M. R., Jayne, J. T., Jimenez, J. L., Allan, J. D., Alfarra, M. R., Zhang, Q., Onasch, T. B., Drewnick, F., Coe, H., Middlebrook, A., Delia, A., Williams, L. R., Trimborn, A. M., Northway, M. J., DeCarlo, P. F., Kolb, C. E., Davidovits, P., and Worsnop, D. R.: Chemical and microphysical characterization of ambient aerosols with the aerodyne aerosol mass spectrometer, Mass Spectrom. Rev., 26, 185-222, doi:10.1002/Mas.20115, 2007.

Canagaratna, M. R., Jimenez, J. L., Kroll, J. H., Chen, Q., Kessler, S. H., Massoli, P., Hildebrandt Ruiz, L., Fortner, E., Williams, L. R., Wilson, K. R., Surratt, J. D., Donahue, N. M., Jayne, J. T., and Worsnop, D. R.: Elemental ratio measurements of organic compounds using aerosol mass spectrometry: characterization, improved calibration, and implications, Atmos. Chem. Phys., 15, 253-272, doi:10.5194/acp-15-253-2015, 2015.

Cao, J. J., Xu, H. M., Xu, Q., Chen, B. H., and Kan, H. D.: Fine Particulate Matter Constituents and Cardiopulmonary Mortality in a Heavily Polluted Chinese City, Environ. Health Persp., 120, 373-378, doi:10.1289/ehp.1103671, 2012.

Carslaw, D. C. and Beevers, S. D.: Characterising and understanding emission sources using bivariate polar plots and k-means clustering, Environ. Model. Soft., 40, 325-329, doi:10.1016/j.envsoft.2012.09.005, 2013.

Carslaw, K. S., Boucher, O., Spracklen, D. V., Mann, G. W., Rae, J. G. L., Woodward, S., and Kulmala, M.: A review of natural aerosol interactions and feedbacks within the Earth system, Atmos. Chem. Phys., 10, 1701-1737, doi:10.5194/acp-10-17012010, 2010.

Chen, C., Sun, Y. L., Xu, W. Q., Du, W., Zhou, L. B., Han, T. T., Wang, Q. Q., Fu, P. Q., Wang, Z. F., Gao, Z. Q., Zhang, Q., and Worsnop, D. R.: Characteristics and sources of submicron aerosols above the urban canopy $(260 \mathrm{~m})$ in Beijing, China, during the 2014 APEC summit, Atmos. Chem. Phys., 15, 1287912895, doi:10.5194/acp-15-12879-2015, 2015.

Collier, S., Zhou, S., Kuwayama, T., Forestieri, S., Brady, J., Zhang, M., Kleeman, M., Cappa, C., Bertram, T., and Zhang, Q.: Organic PM Emissions from Vehicles: Composition, O / C Ratio, 
and Dependence on PM Concentration, Aerosol Sci. Tech., 49, 86-97, doi:10.1080/02786826.2014.1003364, 2015.

DeCarlo, P. F., Slowik, J. G., Worsnop, D. R., Davidovits, P., and Jimenez, J. L.: Particle morphology and density characterization by combined mobility and aerodynamic diameter measurements. Part 1: Theory, Aerosol Sci. Tech., 38, 1185-1205, doi:10.1080/02786820590928897, 2004.

DeCarlo, P. F., Kimmel, J. R., Trimborn, A., Northway, M. J., Jayne, J. T., Aiken, A. C., Gonin, M., Fuhrer, K., Horvath, T., Docherty, K. S., Worsnop, D. R., and Jimenez, J. L.: Field-deployable, high-resolution, time-of-flight aerosol mass spectrometer, Anal. Chem., 78, 8281-8289, doi:10.1021/Ac061249n, 2006.

Denjean, C., Formenti, P., Picquet-Varrault, B., Pangui, E., Zapf, P., Katrib, Y., Giorio, C., Tapparo, A., Monod, A., Temime-Roussel, B., Decorse, P., Mangeney, C., and Doussin, J. F.: Relating hygroscopicity and optical properties to chemical composition and structure of secondary organic aerosol particles generated from the ozonolysis of $\alpha$-pinene, Atmos. Chem. Phys., 15, 3339-3358, doi:10.5194/acp-15-3339-2015, 2015.

Dong, H.-B., Zeng, L.-M., Hu, M., Wu, Y.-S., Zhang, Y.-H., Slanina, J., Zheng, M., Wang, Z.-F., and Jansen, R.: Technical Note: The application of an improved gas and aerosol collector for ambient air pollutants in China, Atmos. Chem. Phys., 12, 1051910533, doi:10.5194/acp-12-10519-2012, 2012.

Drewnick, F., Hings, S. S., DeCarlo, P., Jayne, J. T., Gonin, M., Fuhrer, K., Weimer, S., Jimenez, J. L., Demerjian, K. L., Borrmann, S., and Worsnop, D. R.: A new time-of-flight aerosol mass spectrometer (TOF-AMS) - Instrument description and first field deployment, Aerosol Sci. Tech., 39, 637-658, doi:10.1080/02786820500182040, 2005.

Du, W., Sun, Y. L., Xu, Y. S., Jiang, Q., Wang, Q. Q., Yang, W., Wang, F., Bai, Z. P., Zhao, X. D., and Yang, Y. C.: Chemical characterization of submicron aerosol and particle growth events at a national background site ( 3295 ma.s.l.) on the Tibetan Plateau, Atmos. Chem. Phys., 15, 10811-10824, doi:10.5194/acp-1510811-2015, 2015.

Duplissy, J., DeCarlo, P. F., Dommen, J., Alfarra, M. R., Metzger, A., Barmpadimos, I., Prevot, A. S. H., Weingartner, E., Tritscher, T., Gysel, M., Aiken, A. C., Jimenez, J. L., Canagaratna, M. R., Worsnop, D. R., Collins, D. R., Tomlinson, J., and Baltensperger, U.: Relating hygroscopicity and composition of organic aerosol particulate matter, Atmos. Chem. Phys., 11, 11551165, doi:10.5194/acp-11-1155-2011, 2011.

Fröhlich, R., Cubison, M. J., Slowik, J. G., Bukowiecki, N., Prévôt, A. S. H., Baltensperger, U., Schneider, J., Kimmel, J. R., Gonin, M., Rohner, U., Worsnop, D. R., and Jayne, J. T.: The ToF-ACSM: a portable aerosol chemical speciation monitor with TOFMS detection, Atmos. Meas. Tech., 6, 3225-3241, doi:10.5194/amt-6-3225-2013, 2013.

Fu, Q. Y., Zhuang, G. S., Wang, J., Xu, C., Huang, K., Li, J., Hou, B., Lu, T., and Streets, D. G.: Mechanism of formation of the heaviest pollution episode ever recorded in the Yangtze River Delta, China, Atmos. Environ., 42, 2023-2036, doi:10.1016/j.atmosenv.2007.12.002, 2008.

Ge, X. L., Zhang, Q., Sun, Y., Ruehl, C. R., and Setyan, A.: Effect of aqueous-phase processing on aerosol chemistry and size distributions in Fresno, California, during wintertime, Environ. Chem., 9, 221-235, doi:10.1071/EN11168, 2012a.
Ge, X. L., Setyan, A., Sun, Y., and Zhang, Q.: Primary and secondary organic aerosols in Fresno, California during wintertime: Results from high resolution aerosol mass spectrometry, J. Geophys. Res.-Atmos., 117, D19301, doi:10.1029/2012jd018026, 2012 b.

Ghan, S. J. and Schwartz, S. E.: Aerosol properties and processes: A path from field and laboratory measurements to global climate models, B. Am. Meteorol. Soc., 88, 1059-1083, doi:10.1175/bams-88-7-1059, 2007.

Han, T., Xu, W., Chen, C., Liu, X., Wang, Q., Li, J., Zhao, X., Du, W., Wang, Z., and Sun, Y.: Chemical apportionment of aerosol optical properties during the Asia-Pacific Economic Cooperation summit in Beijing, China, J. Geophys. Res.-Atmos., 120, 1228112295, doi:10.1002/2015JD023918, 2015.

He, L. Y., Huang, X.-F., Xue, L., Hu, M., Lin, Y., Zheng, J., Zhang, R., and Zhang, Y.-H.: Submicron aerosol analysis and organic source apportionment in an urban atmosphere in Pearl River Delta of China using high-resolution aerosol mass spectrometry, J. Geophys. Res.-Atmos., 116, D12304, doi:10.1029/2010jd014566, 2011.

Heald, C. L., Kroll, J. H., Jimenez, J. L., Docherty, K. S., DeCarlo, P. F., Aiken, A. C., Chen, Q., Martin, S. T., Farmer, D. K., and Artaxo, P.: A simplified description of the evolution of organic aerosol composition in the atmosphere, Geophys. Res. Lett., 37, L08803, doi:10.1029/2010g1042737, 2010.

Hu, J., Ying, Q., Wang, Y., and Zhang, H.: Characterizing multi-pollutant air pollution in China: Comparison of three air quality indices, Environ. Int., 84, 17-25, doi:10.1016/j.envint.2015.06.014, 2015.

Hu, W. W., Hu, M., Yuan, B., Jimenez, J. L., Tang, Q., Peng, J. F., Hu, W., Shao, M., Wang, M., Zeng, L. M., Wu, Y. S., Gong, Z. H., Huang, X. F., and He, L. Y.: Insights on organic aerosol aging and the influence of coal combustion at a regional receptor site of central eastern China, Atmos. Chem. Phys., 13, 10095-10112, doi:10.5194/acp-13-10095-2013, 2013.

Hu, X., Zhang, Y., Ding, Z. H., Wang, T. J., Lian, H. Z., Sun, Y. Y., and $\mathrm{Wu}$, J. C.: Bioaccessibility and health risk of arsenic and heavy metals $(\mathrm{Cd}, \mathrm{Co}, \mathrm{Cr}, \mathrm{Cu}, \mathrm{Ni}, \mathrm{Pb}, \mathrm{Zn}$ and $\mathrm{Mn}$ ) in TSP and $\mathrm{PM}_{2.5}$ in Nanjing, China, Atmos. Environ., 57, 146-152, doi:10.1016/j.atmosenv.2012.04.056, 2012.

Huang, X., Xue, L., Tian, X.-D., Shao, W.-W., Sun, T.-L., Gong, Z.-H., Ju, W.-W., Jiang, B., Hu, M., and He, L.Y.: Highly time-resolved carbonaceous aerosol characterization in Yangtze River Delta of China: composition, mixing state and secondary formation, Atmos. Environ., 64, 200-207, doi:10.1016/j.atmosenv.2012.09.059, 2013.

Huang, X.-F., He, L.-Y., Hu, M., Canagaratna, M. R., Sun, Y., Zhang, Q., Zhu, T., Xue, L., Zeng, L.-W., Liu, X.-G., Zhang, Y.-H., Jayne, J. T., Ng, N. L., and Worsnop, D. R.: Highly time-resolved chemical characterization of atmospheric submicron particles during 2008 Beijing Olympic Games using an Aerodyne High-Resolution Aerosol Mass Spectrometer, Atmos. Chem. Phys., 10, 8933-8945, doi:10.5194/acp-10-8933-2010, 2010.

Huang, X.-F., He, L.-Y., Hu, M., Canagaratna, M. R., Kroll, J. H., Ng, N. L., Zhang, Y.-H., Lin, Y., Xue, L., Sun, T.-L., Liu, X.-G., Shao, M., Jayne, J. T., and Worsnop, D. R.: Characterization of submicron aerosols at a rural site in Pearl River Delta of China using an Aerodyne High-Resolution Aerosol Mass Spectrometer, 
Atmos. Chem. Phys., 11, 1865-1877, doi:10.5194/acp-11-18652011, 2011.

Huang, X.-F., He, L.-Y., Xue, L., Sun, T.-L., Zeng, L.-W., Gong, Z.-H., Hu, M., and Zhu, T.: Highly time-resolved chemical characterization of atmospheric fine particles during 2010 Shanghai World Expo, Atmos. Chem. Phys., 12, 4897-4907, doi:10.5194/acp-12-4897-2012, 2012.

Jayne, J. T., Leard, D. C., Zhang, X., Davidovits, P., Smith, K. A., Kolb, C. E., and Worsnop, D. R.: Development of an Aerosol Mass Spectrometer for Size and Composition Analysis of Submicron Particles, Aerosol Sci. Tech., 33, 49-70, doi:10.1016/S0021-8502(98)00158-X, 2000.

Jiang, Q., Sun, Y. L., Wang, Z., and Yin, Y.: Aerosol composition and sources during the Chinese Spring Festival: fireworks, secondary aerosol, and holiday effects, Atmos. Chem. Phys., 15, 6023-6034, doi:10.5194/acp-15-6023-2015, 2015.

Jimenez, J. L., Jayne, J. T., Shi, Q., Kolb, C. E., Worsnop, D. R., Yourshaw, I., Seinfeld, J. H., Flagan, R. C., Zhang, X. F., Smith, K. A., Morris, J. W., and Davidovits, P.: Ambient aerosol sampling using the Aerodyne Aerosol Mass Spectrometer, J. Geophys. Res.-Atmos., 108, 8425, doi:10.1029/2001jd001213, 2003.

Jimenez, J. L., Canagaratna, M. R., Donahue, N. M., Prevot, A. S. H., Zhang, Q., Kroll, J. H., DeCarlo, P. F., Allan, J. D., Coe, H., Ng, N. L., Aiken, A. C., Docherty, K. S., Ulbrich, I. M., Grieshop, A. P., Robinson, A. L., Duplissy, J., Smith, J. D., Wilson, K. R., Lanz, V. A., Hueglin, C., Sun, Y. L., Tian, J., Laaksonen, A., Raatikainen, T., Rautiainen, J., Vaattovaara, P., Ehn, M., Kulmala, M., Tomlinson, J. M., Collins, D. R., Cubison, M. J., Dunlea, E. J., Huffman, J. A., Onasch, T. B., Alfarra, M. R., Williams, P. I., Bower, K., Kondo, Y., Schneider, J., Drewnick, F., Borrmann, S., Weimer, S., Demerjian, K., Salcedo, D., Cottrell, L., Griffin, R., Takami, A., Miyoshi, T., Hatakeyama, S., Shimono, A., Sun, J. Y., Zhang, Y. M., Dzepina, K., Kimmel, J. R., Sueper, D., Jayne, J. T., Herndon, S. C., Trimborn, A. M., Williams, L. R., Wood, E. C., Middlebrook, A. M., Kolb, C. E., Baltensperger, U., and Worsnop, D. R.: Evolution of organic aerosols in the atmosphere, Science, 326, 1525-1529, doi:10.1126/science.1180353, 2009.

Kong, S. F., Li, L., Li, X. X., Yin, Y., Chen, K., Liu, D. T., Yuan, L., Zhang, Y. J., Shan, Y. P., and Ji, Y. Q.: The impacts of firework burning at the Chinese Spring Festival on air quality: insights of tracers, source evolution and aging processes, Atmos. Chem. Phys., 15, 2167-2184, doi:10.5194/acp-15-2167-2015, 2015.

Kulmala, M., Lappalainen, H. K., Petäjä, T., Kurten, T., Kerminen, V.-M., Viisanen, Y., Hari, P., Sorvari, S., Bäck, J., Bondur, V., Kasimov, N., Kotlyakov, V., Matvienko, G., Baklanov, A., Guo, H. D., Ding, A., Hansson, H.-C., and Zilitinkevich, S.: Introduction: The Pan-Eurasian Experiment (PEEX) multidisciplinary, multiscale and multicomponent research and capacity-building initiative, Atmos. Chem. Phys., 15, 1308513096, doi:10.5194/acp-15-13085-2015, 2015.

Lee, A. K. Y., Hayden, K. L., Herckes, P., Leaitch, W. R., Liggio, J., Macdonald, A. M., and Abbatt, J. P. D.: Characterization of aerosol and cloud water at a mountain site during WACS 2010: secondary organic aerosol formation through oxidative cloud processing, Atmos. Chem. Phys., 12, 7103-7116, doi:10.5194/acp-12-7103-2012, 2012.

Lee, B. P., Li, Y. J., Yu, J. Z., Louie, P. K. K., and Chan, C. K.: Physical and chemical characterization of ambient aerosol by HR-ToF-AMS at a suburban site in Hong Kong during springtime 2011, J. Geophys. Res.-Atmos., 118, 8625-8639, doi:10.1002/jgrd.50658, 2013.

Li, Y. J., Lee, B. P., Su, L., Fung, J. C. H., and Chan, C. K.: Seasonal characteristics of fine particulate matter (PM) based on highresolution time-of-flight aerosol mass spectrometric (HR-ToFAMS) measurements at the HKUST Supersite in Hong Kong, Atmos. Chem. Phys., 15, 37-53, doi:10.5194/acp-15-37-2015, 2015.

Malm, W. C. and Day, D. E.: Estimates of aerosol species scattering characteristics as a function of relative humidity, Atmos. Environ., 35, 2845-2860, doi:10.1016/S1352-2310(01)00077-2, 2001.

Matthew, B. M., Middlebrook, A. M., and Onasch, T. B.: Collection Efficiencies in an Aerodyne Aerosol Mass Spectrometer as a Function of Particle Phase for Laboratory Generated Aerosols, Aerosol Sci.Tech., 42, 884-898, doi:10.1080/02786820802356797, 2008.

Middlebrook, A. M., Bahreini, R., Jimenez, J. L., and Canagaratna, M. R.: Evaluation of Composition-Dependent Collection Efficiencies for the Aerodyne Aerosol Mass Spectrometer using Field Data, Aerosol Sci. Tech., 46, 258-271, doi:10.1080/02786826.2011.620041, 2012.

Mohr, C., DeCarlo, P. F., Heringa, M. F., Chirico, R., Slowik, J. G., Richter, R., Reche, C., Alastuey, A., Querol, X., Seco, R., Peñuelas, J., Jiménez, J. L., Crippa, M., Zimmermann, R., Baltensperger, U., and Prévôt, A. S. H.: Identification and quantification of organic aerosol from cooking and other sources in Barcelona using aerosol mass spectrometer data, Atmos. Chem. Phys., 12, 1649-1665, doi:10.5194/acp-12-1649-2012, 2012.

Mohr, C., DeCarlo, P. F., Heringa, M. F., Chirico, R., Richter, R., Crippa, M., Querol, X., Baltensperger, U., and Prévôt, A. S. H.: Spatial Variation of Aerosol Chemical Composition and Organic Components Identified by Positive Matrix Factorization in the Barcelona Region, Environ. Sci. Technol., 49, 10421-10430, doi:10.1021/acs.est.5b02149, 2015.

Ng, N. L., Canagaratna, M. R., Zhang, Q., Jimenez, J. L., Tian, J., Ulbrich, I. M., Kroll, J. H., Docherty, K. S., Chhabra, P. S., Bahreini, R., Murphy, S. M., Seinfeld, J. H., Hildebrandt, L., Donahue, N. M., DeCarlo, P. F., Lanz, V. A., Prévôt, A. S. H., Dinar, E., Rudich, Y., and Worsnop, D. R.: Organic aerosol components observed in Northern Hemispheric datasets from Aerosol Mass Spectrometry, Atmos. Chem. Phys., 10, 46254641, doi:10.5194/acp-10-4625-2010, 2010.

Ng, N. L., Herndon, S. C., Trimborn, A., Canagaratna, M. R., Croteau, P. L., Onasch, T. B., Sueper, D., Worsnop, D. R., Zhang, Q., Sun, Y. L., and Jayne, J. T.: An Aerosol Chemical Speciation Monitor (ACSM) for Routine Monitoring of the Composition and Mass Concentrations of Ambient Aerosol, Aerosol Sci. Tech., 45, 770-784, doi:10.1080/02786826.2011.560211, 2011.

Onasch, T. B., Trimborn, A., Fortner, E. C., Jayne, J. T., Kok, G. L., Williams, L. R., Davidovits, P., and Worsnop, D. R. Soot particle aerosol mass spectrometer: Development, validation, and initial application, Aerosol Sci. Tech., 46, 804-817, doi:10.1080/02786826.2012.663948, 2012.

Onasch, T. B., Fortner, E. C., Trimborn, A. M., Lambe, A. T., Tiwari, A. J., Marr, L. C., Corbin, J. C., Mensah, A. A., Williams, L. R., Davidovits, P., and Worsnop, D. R.: Investigations of SP-AMS Carbon Ion Distributions as a Function of Refractory 
Black Carbon Particle Type, Aerosol Sci. Tech., 49, 409-422, doi:10.1080/02786826.2015.1039959, 2015.

Paatero, P. and Tapper, U.: Positive matrix factorization: A non-negative factor model with optimal utilization of error estimates of data values, Environmetrics, 5, 111-126, doi:10.1002/env.3170050203, 1994.

Pope, C. A. and Dockery, D. W.: Health Effects of Fine Particulate Air Pollution: Lines that Connect, J. Air Waste Manage., 56, 709-742, doi:10.1080/10473289.2006.10464485, 2006.

Pöschl, U.: Atmospheric Aerosols: Composition, Transformation, Climate and Health Effects, Angew. Chem. Int. Edit., 44, 75207540, doi:10.1002/anie.200501122, 2005.

Qi, L., Zhang, Y., Ma, Y., Chen, M., Ge, X., Ma, Y., Zheng, J., Wang, Z., and Li, S.: Source identification of trace elements in the atmosphere during the second Asian Youth Games in Nanjing, China: Influence of control measures on air quality, Atmos. Pollut. Res., 7, 547-556, doi:10.1016/j.apr.2016.01.003, 2016.

Seinfeld, J. H. and Pandis, S. N.: Atmospheric Chemistry and Physics: From Air Pollution to Climate Change, John Wiley \& Sons, New York, USA, 2006.

Setyan, A., Zhang, Q., Merkel, M., Knighton, W. B., Sun, Y., Song, C., Shilling, J. E., Onasch, T. B., Herndon, S. C., Worsnop, D. R., Fast, J. D., Zaveri, R. A., Berg, L. K., Wiedensohler, A., Flowers, B. A., Dubey, M. K., and Subramanian, R.: Characterization of submicron particles influenced by mixed biogenic and anthropogenic emissions using high-resolution aerosol mass spectrometry: results from CARES, Atmos. Chem. Phys., 12, 8131-8156, doi:10.5194/acp-12-8131-2012, 2012.

Shen, G. F., Yuan, S. Y., Xie, Y. N., Xia, S. J., Li, L., Yao, Y. K., Qiao, Y. Z., Zhang, J., Zhao, Q. Y., Ding, A. J., Li, B., and $\mathrm{Wu}, \mathrm{H}$. S.: Ambient levels and temporal variations of $\mathrm{PM}_{2.5}$ and $\mathrm{PM}_{10}$ at a residential site in the mega-city, Nanjing, in the western Yangtze River Delta, China, J. Environ. Sci. Health., Part A, 49, 171-178, doi:10.1080/10934529.2013.838851, 2014.

Shen, X. J., Sun, J. Y., Zhang, X. Y., Zhang, Y. M., Zhang, L., Che, H. C., Ma, Q. L., Yu, X. M., Yue, Y., and Zhang, Y. W.: Characterization of submicron aerosols and effect on visibility during a severe haze-fog episode in Yangtze River Delta, China, Atmos. Environ., 120, 307-316, doi:10.1016/j.atmosenv.2015.09.011, 2015.

Sun, Y., Jiang, Q., Wang, Z., Fu, P., Li, J., Yang, T., and Yin, Y.: Investigation of the Sources and Evolution Processes of Severe Haze Pollution in Beijing in January 2013, J. Geophys. Res.Atmos., 119, 4380-4398, doi:10.1002/2014JD021641, 2014.

Sun, Y.-L., Zhang, Q., Schwab, J. J., Demerjian, K. L., Chen, W.N., Bae, M.-S., Hung, H.-M., Hogrefe, O., Frank, B., Rattigan, O. V., and Lin, Y.-C.: Characterization of the sources and processes of organic and inorganic aerosols in New York city with a high-resolution time-of-flight aerosol mass apectrometer, Atmos. Chem. Phys., 11, 1581-1602, doi:10.5194/acp-11-15812011, 2011.

Sun, Y. L., Du, W., Wang, Q., Zhang, Q., Chen, C., Chen, Y., Chen, Z., Fu, P., Wang, Z., Gao, Z., and Worsnop, D. R.: Real-Time Characterization of Aerosol Particle Composition above the Urban Canopy in Beijing: Insights into the Interactions between the Atmospheric Boundary Layer and Aerosol Chemistry, Environ. Sci. Technol., 49, 11340-11347, doi:10.1021/acs.est.5b02373, 2015a.
Sun, Y. L., Wang, Z. F., Du, W., Zhang, Q., Wang, Q. Q., Fu, P. Q., Pan, X. L., Li, J., Jayne, J., and Worsnop, D. R.: Longterm real-time measurements of aerosol particle composition in Beijing, China: seasonal variations, meteorological effects, and source analysis, Atmos. Chem. Phys., 15, 10149-10165, doi:10.5194/acp-15-10149-2015, 2015b.

Sun, Y. L., Wang, Z., Wild, O., Xu, W., Chen, C., Fu, P., Du, W., Zhou, L., Zhang, Q., Han, T., Wang, Q., Pan, X., Zheng, H., Li, J., Guo, X., Liu, J., and Worsnop, D. R.: "APEC Blue": Secondary Aerosol Reductions from Emission Controls in Beijing, Sci. Rep., 6, 20668, doi:10.1038/srep20668, 2016.

Tang, L., Yu, H., Ding, A., Zhang, Y., Qin, W., Wang, Z., Chen, W., Hua, Y., and Yang, X.: Regional contribution to PM1 pollution during winter haze in Yangtze River Delta, China, Sci. Total Environ., 541, 161-166, doi:10.1016/j.scitotenv.2015.05.058, 2016.

Ulbrich, I. M., Canagaratna, M. R., Zhang, Q., Worsnop, D. R., and Jimenez, J. L.: Interpretation of organic components from Positive Matrix Factorization of aerosol mass spectrometric data, Atmos. Chem. Phys., 9, 2891-2918, doi:10.5194/acp-9-2891-2009, 2009.

Wang, G. H., Niu, S. L., Liu, C., and Wang, L. S.: Identification of dicarboxylic acids and aldehyde of $\mathrm{PM}_{10}$ and $\mathrm{PM}_{2.5}$ aerosols in Nanjing, China, Atmos. Environ., 36, 1941-1950, doi:10.1016/s1352-2310(02)00180-2, 2002.

Wang, G. H., Wang, H., Yu, Y. J., Gao, S. X., Feng, J. F., Gao, S. T., and Wang, L. S.: Chemical characterization of water-soluble components of $\mathrm{PM}_{10}$ and $\mathrm{PM}_{2.5}$ atmospheric aerosols in five locations of Nanjing, China, Atmos. Environ., 37, 2893-2902, doi:10.1016/s1352-2310(03)00271-1, 2003.

Wang, G. H., Kawamura, K., Xie, M. J., Hu, S. Y., Cao, J. J., An, Z. S., Waston, J. G., and Chow, J. C.: Organic molecular compositions and size distributions of Chinese summer and autumn aerosols from Nanjing: Characteristic haze event caused by wheat straw burning, Environ. Sci. Technol., 43, 6493-6499, doi:10.1021/es803086g, 2009.

Wang, G. H., Chen, C. L., Li, J. J., Zhou, B. H., Xie, M. J., Hu, S. Y., Kawamura, K., and Chen, Y.: Molecular composition and size distribution of sugars, sugar-alcohols and carboxylic acids in airborne particles during a severe urban haze event caused by wheat straw burning, Atmos. Environ., 45, 2473-2479, doi:10.1016/j.atmosenv.2011.02.045, 2011.

Wang, J., Onasch, T. B., Ge, X., Collier, S., Zhang, Q., Sun, Y., Yu, H., Chen, M., Prévôt, A. S. H., and Worsnop, D. R.: Observation of Fullerene Soot in Eastern China, Environ. Sci. Technol. Lett., 3, 121-126, doi:10.1021/acs.estlett.6b00044, 2016.

Wang, Q., Sun, Y., Jiang, Q., Du, W., Sun, C., Fu, P., and Wang, Z.: Chemical composition of aerosol particles and light extinction apportionment before and during the heating season in Beijing, China, J. Geophys. Res.-Atmos., 120, 12708-12722, doi:10.1002/2015JD023871, 2015.

Wang, Q., Zhao, J., Du, W., Ana, G., Wang, Z., Sun, L., Wang, Y., Zhang, F., Li, Z., Ye, X., and Sun, Y.: Characterization of submicron aerosols at a suburban site in central China, Atmos Environ, 131, 115-123, doi:10.1016/j.atmosenv.2016.01.054, 2016.

Wexler, A. S. and Johnston, M. V.: What have we learned from highly time-resolved measurements during EPA's Supersites program,and related studies?, J. Air Waste Manage., 58, 303-319, doi:10.3155/1047-3289.58.2.303, 2008. 
Xu, J., Zhang, Q., Chen, M., Ge, X., Ren, J., and Qin, D.: Chemical composition, sources, and processes of urban aerosols during summertime in northwest China: insights from high-resolution aerosol mass spectrometry, Atmos. Chem. Phys., 14, 1259312611, doi:10.5194/acp-14-12593-2014, 2014.

Xu, W. Q., Sun, Y. L., Chen, C., Du, W., Han, T. T., Wang, Q. Q., Fu, P. Q., Wang, Z. F., Zhao, X. J., Zhou, L. B., Ji, D. S., Wang, P. C., and Worsnop, D. R.: Aerosol composition, oxidation properties, and sources in Beijing: results from the 2014 Asia-Pacific Economic Cooperation summit study, Atmos. Chem. Phys., 15, 13681-13698, doi:10.5194/acp-15-13681-2015, 2015.

Yan, J., Chen, L., Lin, Q., Li, Z., Chen, H., and Zhao, S.: Chemical characteristics of submicron aerosol particles during a longlasting haze episode in Xiamen, China, Atmos. Environ., 113, 118-126, doi:10.1016/j.atmosenv.2015.05.003, 2015.

Yang, H., Yu, J. Z., Ho, S. S. H., Xu, J. H., Wu, W. S., Wan, C. H., Wang, X. D., Wang, X. R., and Wang, L. S.: The chemical composition of inorganic and carbonaceous materials in $\mathrm{PM}_{2.5}$ in Nanjing, China, Atmos. Environ., 39, 3735-3749, doi:10.1016/j.atmosenv.2005.03.010, 2005.

Yang, L.-X., Wang, D.-C., Cheng, S.-H., Wang, Z., Zhou, Y., Zhou, X.-H., and Wang, W.-X.: Influence of meteorological conditions and particulate matter on visual range impairment in Jinan, China, Sci. Total Environ., 383, 164-173, doi:10.1016/j.scitotenv.2007.04.042, 2007.

Yeung, M. C., Lee, B. P., Li, Y. J., and Chan, C. K.: Simultaneous HTDMA and HR-ToF-AMS measurements at the HKUST Supersite in Hong Kong in 2011, J. Geophys. Res.-Atmos., 119, 9864-9883, doi:10.1002/2013JD021146, 2014.

Young, D. E., Kim, H., Parworth, C., Zhou, S., Zhang, X., Cappa, C. D., Seco, R., Kim, S., and Zhang, Q.: Influences of emission sources and meteorology on aerosol chemistry in a polluted urban environment: results from DISCOVER-AQ California, Atmos. Chem. Phys., 16, 5427-5451, doi:10.5194/acp-16-54272016, 2016.

Yu, L., Smith, J., Laskin, A., Anastasio, C., Laskin, J., and Zhang, Q.: Chemical characterization of SOA formed from aqueousphase reactions of phenols with the triplet excited state of carbonyl and hydroxyl radical, Atmos. Chem. Phys., 14, 1380113816, doi:10.5194/acp-14-13801-2014, 2014.

Zhang, J. K., Sun, Y., Liu, Z. R., Ji, D. S., Hu, B., Liu, Q., and Wang, Y. S.: Characterization of submicron aerosols during a month of serious pollution in Beijing, 2013, Atmos. Chem. Phys., 14, 2887-2903, doi:10.5194/acp-14-2887-2014, 2014.
Zhang, J. K., Wang, L. L., Wang, Y. H., and Wang, Y. S.: Submicron aerosols during the Beijing Asia-Pacific Economic Cooperation conference in 2014, Atmos. Environ., 124, Part B, 224-231, doi:10.1016/j.scitotenv.2007.04.042, 2016.

Zhang, Q., Alfarra, M. R., Worsnop, D. R., Allan, J. D., Coe, H., Canagaratna, M. R., and Jimenez, J. L.: Deconvolution and quantification of hydrocarbon-like and oxygenated organic aerosols based on aerosol mass spectrometry, Environ. Sci. Technol., 39, 4938-4952, doi:10.1021/Es0485681, 2005.

Zhang, Q., Jimenez, J. L., Canagaratna, M. R., Allan, J. D., Coe, H., Ulbrich, I., Alfarra, M. R., Takami, A., Middlebrook, A. M., Sun, Y. L., Dzepina, K., Dunlea, E., Docherty, K., DeCarlo, P. F., Salcedo, D., Onasch, T., Jayne, J. T., Miyoshi, T., Shimono, A., Hatakeyama, S., Takegawa, N., Kondo, Y., Schneider, J., Drewnick, F., Borrmann, S., Weimer, S., Demerjian, K., Williams, P., Bower, K., Bahreini, R., Cottrell, L., Griffin, R. J., Rautiainen, J., Sun, J. Y., Zhang, Y. M., and Worsnop, D. R.: Ubiquity and dominance of oxygenated species in organic aerosols in anthropogenically-influenced Northern Hemisphere midlatitudes, Geophys. Res. Lett., 34, L13801, doi:10.1029/2007gl029979, 2007a.

Zhang, Q., Jimenez, J. L., Worsnop, D. R., and Canagaratna, M.: A case study of urban particle acidity and its influence on secondary organic aerosol, Environ. Sci. Technol., 41, 3213-3219, doi:10.1021/Es061812j, 2007b.

Zhang, Q., Jimenez, J., Canagaratna, M., Ulbrich, I., Ng, N., Worsnop, D., and Sun, Y.: Understanding atmospheric organic aerosols via factor analysis of aerosol mass spectrometry: a review, Anal. Bioanal. Chem., 401, 3045-3067, doi:10.1007/s00216-011-5355-y, 2011.

Zhang, Y. J., Tang, L. L., Wang, Z., Yu, H. X., Sun, Y. L., Liu, D., Qin, W., Canonaco, F., Prévôt, A. S. H., Zhang, H. L., and Zhou, H. C.: Insights into characteristics, sources, and evolution of submicron aerosols during harvest seasons in the Yangtze River delta region, China, Atmos. Chem. Phys., 15, 1331-1349, doi:10.5194/acp-15-1331-2015, 2015.

Zhang, Y. J., Tang, L., Yu, H., Wang, Z., Sun, Y., Qin, W., Chen, W., Chen, C., Ding, A., Wu, J., Ge, S., Chen, C., and Zhou, H.-C.: Chemical composition, sources and evolution processes of aerosol at an urban site in Yangtze River Delta, China during wintertime, Atmos. Environ., 123, 339-349, doi:10.1016/j.atmosenv.2015.08.017, 2016. 